\title{
Türkiye'de Bölgesel Planlamanın Kurumsallaşması: Muğlak Bir Süreci Güncel Kuramlar ile Okumak
}

$*$

\author{
Irmak Yavuz ${ }^{1}$ \\ ORCID: 0000-0001-5735-5599
}

\author{
Ecem Kutlay ${ }^{2}$ \\ ORCID: 0000-0002-3406-5115
}

\author{
Deniz Can ${ }^{3}$ \\ ORCID: 0000-0003-2681-526X
}

\section{Öz}

Türkiye'de bölge planlama pratiği sürecinde içerikler, amaçlar ve kurumsal yapılar sürekli olarak değişime uğramıştır. Oluşan karmaşık sistem, bölgesel planların amaçlarını, karar alma mekanizmalarını, sürecin meşruiyetini ve bu planların genel olarak uygulamadaki başarısını da etkilemiştir. Türkiye'de bölgesel planlamada etkili olan karmaşık ve değişken kurumsal yapuları değerlendirmek ve kurumsallaşma dinamiklerini daha iyi anlamak için kurumlar ile birlikte, kurumların organizasyon mekanizmaları, kurumlar arası çatışmalar veya farklı otoriteler arasındaki iş birliklerinin eorimi tartışmanın merkezine alınarak incelenmelidir. Değiş̧en dinamikler, birden çok kurumu ve kurumların ilişkilerini içeren süreçlerin içkin bir parçasıdır. Bu dinamikleri daha iyi anlamak için temel alınacak kuramsal bir çerçeveye ihtiyaç vardır. Bu bağlamda, Türkiye'de bölgesel planlamadaki kurumsallaşmadaki üç ayrı evreyi oluşturan kırlma noktalarinı detaylı bir şekilde incelemek, süreci anlamak ve birimler arasındaki ilişkileri güncel kuram ve kavramlarla tartışmak amactyla; çok bileşenli yapılarm incelenmesine olanak sağlayan asamblaj (assemblage) ve aktör ă̆ kuramlan (actor network) ile kurumsallaşma üzerinde demokratik bir çatkı oluşturan agonizm kuramı çalışmanın temel eksenini oluşturmaktadır.

Anahtar Kelimeler: bölge planlama, kurumsallaşma, asamblaj, aktör ă̆ kuramı, agonism

\footnotetext{
${ }^{1}$ Arş. Gör., TED Üniversitesi, E-mail: irmak.yavuz@tedu.edu.tr

2 Arş. Gör., ODTÜ, E-mail: ecemk@metu.edu.tr

${ }^{3}$ Arş. Gör., ODTÜ, E-mail: denizcan@metu.edu.tr

id ealkent @ C Kent Araştırmaları Dergisi (Journal of Urban Studies)

http://idealkentdergisi.com
}

Geliş Tarihi Received Date: 24.12.2020 Kabul Tarihi Accepted Date: 12.04.2021 


\title{
Institutionalisation of Regional Planning in Turkey: Rendering an Ambiguous Process with Recent Theories
}

\author{
Irmak Yavuz ${ }^{4}$ \\ ORCID: 0000-0001-5735-5599
}

\author{
Ecem Kutlay ${ }^{5}$ \\ ORCID: 0000-0002-3406-5115
}

Deniz Can ${ }^{6}$

ORCID: 0000-0003-2681-526X

\begin{abstract}
Contents, goals and institutional structures have changed continuously in the process of regional planning practices in Turkey. Emerging complex systems affected the aim of regional plans, decision-making mechanisms as well as the legitimacy of the processes and the success in the implementation of these plans. In order to evaluate the complex and changing institutional structures for effective regional planning in Turkey and to better understand the dynamics of institutionalization, the organization mechanisms of the institutions, the conflicts between institutions or the evolution of the collaborations between different authorities should be considered along with the institutions. Changing dynamics are an immanent part of processes involving multiple institutions and the relationships amongst them. To better comprehend these dynamics, a theoretical framework is necessary. In this context, assemblage theory and actor network theory that enable an analysis of multi-component structures and agonism theory that establishes a democratic framework constitute the main axis of the study in examining the institutional dynamics and breaking points and, eventually, in understanding the institutionalization process.
\end{abstract}

Keywords: regional planning, institutionalization, assemblage, actor network theory, agonism

\footnotetext{
${ }^{4}$ R. A., TED University, E-mail: irmak.yavuz@tedu.edu.tr

${ }^{5}$ R. A., METU, E-mail: ecemk@metu.edu.tr

${ }^{6}$ R. A., METU, E-mail: denizcan@metu.edu.tr

idealkent @ C Kent Araştırmaları Dergisi (Journal of Urban Studies)

http://idealkentdergisi.com
}

Geliş Tarihi Received Date: 24.12.2020 Kabul Tarihi Accepted Date: 12.04.2021 


\section{Giriş}

Bölge planlama, devletin sahip olduğu kaynak ve teşviklerin akılcı bir şekilde kullanılması ve bölgelerin sosyal, ekonomik, kültürel ve fiziki açıdan planlanması (Taneri, 1986, s.5) ve geliştirilmesi sürecidir. Bu sürece yönelik hazırlanan planlar, bölgenin kaynaklarını verimli bir şekilde kullanacak esasları belirleyerek, bölgeler arası eşitsizliklerin giderilmesini ve bölgelerin kalkınmasını amaçlamaktadır. Türkiye'de bölge planlama pratiği sürecinde içerikler, amaçlar ve kurumsal yapılar sürekli olarak değişime uğramıştır. Kurumsal çerçeve ve kurumların yetki sınırlarındaki değişiklikler ile kurumlar arası görev transferleri bölgesel planların amaçlarını, karar alma mekanizmalarını ve bu planların genel olarak uygulamadaki başarısını da etkilemiştir. 1960'larda Devlet Planlama Teşkilatı ile başlayan bölge planlamasının kurumsal yapısı son yıllardaki değişimler sonucu parçacıl bir yapı kazanmıştır. Bu durum birbiriyle iş birliği içinde olmayan kurumların ve farklı kurumlar tarafindan farklı amaçlar doğrultusunda üretilen birbirinden bağımsız bölge planlarının ortaya çıkmasına yol açmıştır. Aynı zamanda, Avrupa Birliği uyum sürecinin Türkiye'nin birçok bölgesinde Kalkınma Ajanslarının kurulmasının önünü açmasıyla, bölgesel dinamikler bir kez daha değişmiş ve süreç içinde bölge planı yapma yetkisine sahip kurum sayısı artmıştır. Bölgesel planlama pratiğindeki bu karmaşık yapı, farklı sorunlara neden olmuş ve planların verimini düşürerek, bölge potansiyellerinin değerlendirilmesini kısıtlamıştır. Süreç içinde evirilen kurumsallaşma yapısının oluşturduğu ilişki şemasını değerlendirmek için güncel kuramlara değinmek, ortaya çkan problemleri bir zemine oturtmakta yardımcı olacak ve ileriye yönelik tartışmaları zenginleştirecektir.

Çalışmanın araştırma sürecinde öncelikle güncel kuramsal kaynaklardan elde edilen bilgiler ile kavramsal çerçeve kurulmuştur. Bu süreci Türkiye'de bölge planlamanın kurumsallaşmasına ilişkin bilgi temelinin oluşturulması ve aktör ağların tanımlanması izlemiştir. Kurumsallaşmada aktör ağ ilişkilerinin incelenmesinde geçmişe yönelik bilginin çeşitli akademik kaynaklardan ve plan raporlarından elde edilmesi yanı sıra güncel bilgiler bölge planlama ile doğrudan ya da dolaylı ilişkisi bulunan kurumların resmi internet sayfaları, Resmî Gazete'deki kanunlar, kanun hükmünde kararnameler ve yönetmelikler esas alınarak elde edilmiştir. Aktör ağ ilişkileri, zaman içinde çeşitli yasal düzenlemelerle değişen kurumların yetki ve görevleri, ve kurumlar arası kademelenmeler ve iş birlikleri esas alınarak oluşturulmuştur. Aktör ağın düğüm noktalarını oluşturan kurumsal yapılar ve bunlar arasındaki bağlar, veri hari- 
talama, analiz etme ve yayımlama arayüzü sunan 'graph commons' kullanılarak işlenmiştir. Böylece zaman içinde bölge planlamanın kurumsallaşmasındaki ağların ve bunların farklılaştığı evreleri tarif eden kırılma noktalarının tespit edilmesi ve bu bilginin güncel kuramsal çerçeveler ile sentezi mümkün olmuştur. Bu anlamda, kurumsal ağların farklılaşttğı evrelerin temel nitelikleri, dinamik ve çok aktörlü yapıların incelenmesine olanak sağlayan asamblaj ve aktör ağ kuramları ve demokratik bir çerçeve sunan agonism kuramı kapsamında ele alınmış, bütüncül ve kapsamlı bir değerlendirme ortaya konmuştur.

\section{Karmaşık Sosyal İlişkileri İnceleyen Bir Bakış Açısı: Asamblaj Kuramı}

Bölgesel planlama dinamiklerinden bahsetmeden önce farklı kuramsal çerçeveleri detaylandırmak, farklı ölçeklerde kurulan ilişkileri ve karmaşık yapıları anlamakta yol gösterecektir. Bu bağlamda, karmaşık sosyal ilişkileri incelemek amaciyla Gilles Deleuze ve Félix Guattari' nin, A Thousand Plateaus (1987) adlı kitabında ilk tohumlarını attığı asamblaj fikrinden bahsetmek gerekir. Bu fikir, temelde asamblajların durağan olmadığını, onları oluşturan parçaların yer değiştirebileceğini ve geçirdikleri sürekli değişimler sonucunda farklı ilişkilerin ortaya çıkabileceğini önermektedir. Thomas Nail (2017), Deleuze ve Guattari'nin asamblaj fikrinin iki ana felsefi sonucu olduğunu söyler: 'çokluk lehine birliğin reddi' ve 'olaylar lehine özün reddi'. Normal bir düzende birliktelikler, parçaları organik bir ilişkiye sahip olan bir bütün olarak tanımlanır ve bir parçanın olmaması durumunda, bir araya gelen parçalar bir bütün olarak işlev göremez. Organik bir birlikteki parçalar, bütünsel sistemin varlığını tehdit ettiği için yeniden birleşim konusunda esnekliğe sahip değillerdir. Öte yandan asamblaj fikrinin ilk felsefi sonucuna göre, birliktelik kuran birimler farklı bir araya gelişler için daha esnek olacak ve dışsal ilişkilerin önemli olduğu mekanizmalar haline gelecektir. Deleuze ve Guattari, dışsal ilişkileriyle tanımlanan bir araya gelişleri makine benzeri asamblaj olarak adlandırır (Nail, 2017, s.2223). Bu nedenle, çokluk (multiplicity), organik olarak ilişki kuran parçalardan ve bir bütünden daha önemlidir. Asamblajlar bir bütün veya parça olarak kabul edilmezler, daha çok çeşitlerin bir araya geldiği çokluklardır; çoklukta önemli olan nokta ise elementlerin kendisinden ziyade aralarındaki ilişkidir (Deleuze ve Parnet, 1987, s.vii-viii). Nail (2017')in asamblaj üzerine yaptığı değerlendirme ve aktarımlara göre, dışsal ilişkilere odaklanma durumunda, birliğe zarar vermeden parçaları (tekillikleri -singularities) değiştirmek, eklemek, çıkarmak veya yeniden düzenlemek mümkündür. Bahsi geçen ikinci felsefi sonuç ise asıl sorulması gereken soruların "Nasıl? Ne zaman? ve Hangi bakış aç1sıyla?" olduğunu vurgular. Böylece asıl odak olaylar üzerine yoğunlaşır. 
Asamblajlar, koşullu tekillikler içeren çokluklardır (Nail, 2017, s.23-24). Bu durum, tanımlanmış bir özleri olmadığı, ancak bir araya gelme olayları olduğu anlamina gelir. Basit bir ifadeyle, tekiller arasındaki olaylar, özlerinden daha ön plandadır. Böylece, sonsuz bir değişime veya şekillenmeye açı olan asamblajların sabit bir toplam olması pek olası değildir (Nail, 2017). Bahsedilen iki temel sonuç, parçalar arasındaki dışsal ilişkilerin ve olayların oluşturacağı karmaşık ilişki sistemlerini değerlendirmek için bir temel oluşturmaktadır.

Deleuze ve Guattari önermesi olan asamblaj fikri, çeşitli araştırmacılar tarafından farklı bağlamlarda ele alınarak geliştirilmiştir. Manuel DeLanda (2006; 2017), bu mantığı sosyal varlıkbilimine yeni bir bakış açısı getirerek değerlendirmiş, fikri bu perspektifle kuramsallaştırmış ve bir araya geliş biçimlerinin genel özelliklerini açıklamıştır. Bu bağlamda asamblajlar tekil varlıklar (individual entities) olarak kabul edilebilir, çünkü hepsinin farklı bir geçmişi vardır. Herhangi bir ölçekte asıl odak, birbiriyle ilişki kuran varlıklardır. Bu varlıklar bütünde yer bulabildiği gibi, bütünden bağımsız kalarak kendi tekil ya da ‘özdeciksel' birlikteliklerini yaratabilirler. Bir asamblaj, kendisini oluşturan parçaları hem sınılayıcı hem de onlara esneklik sağlayıcı nitelikte olmalıdır. Bu noktada, aşağıdan yukarıya bir çerçeve sunan asamblajlar aynı zamanda yukarıdan aşağıya bir kontrol mekanizmasına sahiptir. Yazar, asamblaj kavramının niceliksel olarak daha iyi anlaşılması için, bu fikri iki ana parametre üzerinden açıklar: (1) bölgeselleştirme (territorialization) parametresi, (2) kodlama (coding) parametresi. Bölgeselleştirme parametresi bölgeselleştirme ve yersiz yurtsuzlaştırma (deterritorialization) derecesini; kodlama parametresi ise kodlama ve kod çözme (decoding) derecesini anlamaya yöneliktir (DeLanda, 2017, s.7-8).

Bölgeselleştirme, bir araya gelişlerin sınırını ve kurallarını tanımlarken, yersiz yurtsuzlaştırma asamblajların esnekliğini fakat aynı zamanda bir araya gelişlerin dağılmasına neden olabilecek kararsızlık karakterini tanımlar (Atkinson, 2016, s.71). DeLanda (2017, s.8)'nun belirttiği bir diğer parametre olan kodlama, bütüncül sistemlerin kimliğini düzenlemek için kullanılan dili ifade eder. Yazar burada, otoritelerin meşruluğunun "yazılı kurallar, standart prosedürler ve en önemlisi haklarını ve yükümlülüklerini tanımlayan anayasal bir tüzük" gibi dilsel olarak belirlenmiş ritüeller tarafından tanımlandığı kurumsal yapı örnekleri vermektedir. Bu bağlamda, tüm tekil kurumların bu parametre ile bir araya geldiğini veya düzenlendiğini, ayrıca devletin bölge düzeyinde uyguladığı kodlama işlemlerinin olduğunu söyler.

Clough, Han ve Schiff (2007), bölgeselleştirme / yersiz yurtsuzlaştırma işlemlerinin, kuruluşlarda, hükümetlerde ve mekânsal yargı sınırlarında otorite 
yapılarının meşrulaştırılmasına temel oluşturmak için önemli olduğunu vurgular. Bu bağlamda asamblaj teorisi yerel, bölgesel ve ulusal organizasyonların hiyerarşik yapısı gibi organizasyon ağlarına da atıfta bulunmaktadır. Ayrıca, parçalar veya asamblajlar arasındaki dışsal ilişkiler, organizasyonların bölgeselleştirilmesini veya yersiz yurtsuzlaştırılmasın belirleyebilir (Clough vd. 2007, s.390-391). Burada dişsal ilişkiler ile anlatılmak istenen şeyin, asamblaj içinden ayrılan parçaların farklı asamblajlara eklemlenebileceği ve buralarda farklı ilişkiler kurabileceği, olduğu belirtilmektedir (DeLanda, 2006, s.10). Kurum veya kuruluşların asamblajın parçası olarak kabul edildiği bir senaryoda, farklı etkileşimler ve yeni ilişkiler, bir takım yetki çakışmalarına neden olabilir. DeLanda bu duruma şöyle bir yorum getirir; “birbiriyle örtüşen yarg1 yetkisine sahip kuruluşlar arasında bir çatışma ... ve yargı hak taleplerini uygulamak için ekonomik, askeri veya yasal kaynakların eksikliği, örgütsel kimliği bulanıklaştırabilir" (DeLanda, 2006, s.74) ve yersiz yurtsuzlaştırmaya (deterritorialization) yol açabilir. Manuel DeLanda tarafından genişletilen asamblaj kuramının Deleuze ve Guattari'nin fikirlerine katkısı "mikro analiz seviyesinde bireyler; mezo seviyede gruplar ve organizasyonlar; makro düzeyde ise ülkeler ve sınıflar arasında bağlant kurmak" olmuştur (Atkinson, 2016, s.91). Böylece, asamblaj kuramı hakkındaki bu girdiler, sosyal organizasyonların, kurumların ve kurumsal yapıların oluşumlarını ve ilişkilerini incelemek için yönlendirici bir eksen oluşturmaktadır.

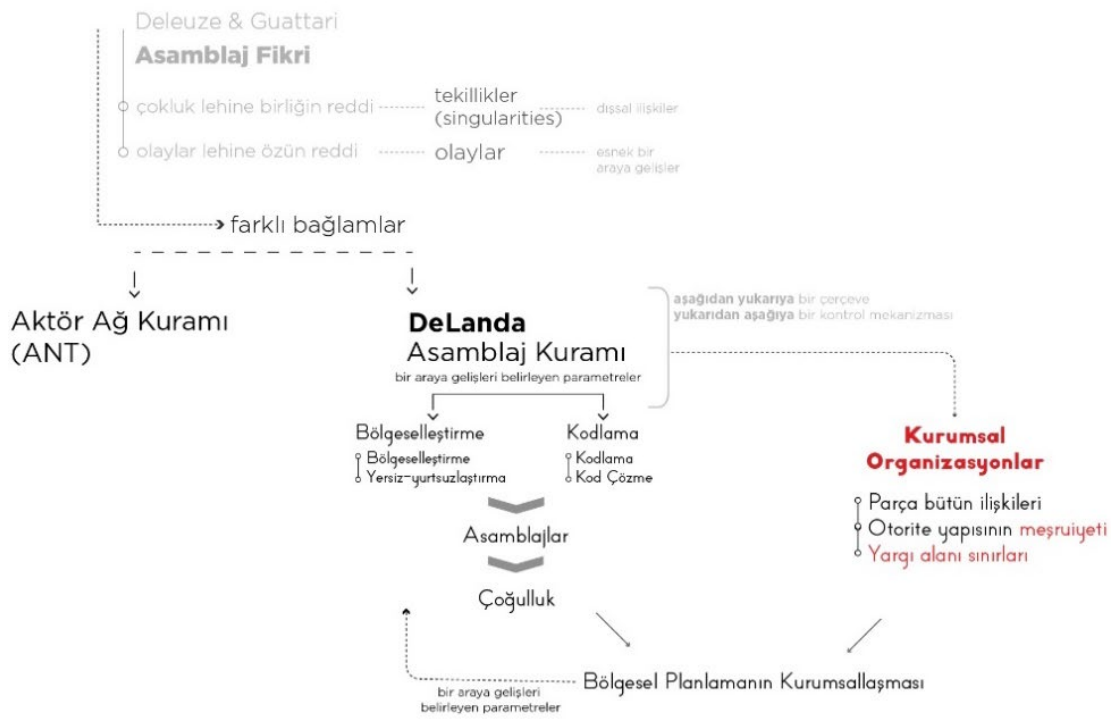

Şekil 1: Bölgesel planlama ve kurumsallaşmanın asamblaj teorisi çerçevesinde konumlandırılması 
Asamblaj kuramı, araştırmacılara yeni bakış açıları sunmuş ve kuramı yeniden ele alış biçimlerine esneklikle cevap vermiştir. Çeşitli araştırmacılar, asamblaj kuramı ile aktör ağ kuramının benzerlikler içerdiğinden bahsetmektedir (bkz. Müller ve Schurr, 2016). Bu kapsamda aktör ağ kuramı, hem kendi içinde tutarlı bir bütün oluşturan özerk unsurlara (Latour'dan akt. Kayasü ve Yetişkul, 2013, s.148), hem de bütünü oluşturan ağın kendisine odaklanır. Bu kuram genel olarak post yapısalcı araştırmacılar tarafından "dünyayı epistemolojik temellerden ziyade üretken ve ontolojik temeller üzerine inşa eden bir araştırma sürecinin çıktısı olarak gören yeni bir kuram" olarak ortaya konmuştur (Ruming, 2009, s.452). Bu yaklaşımda dünyanın kapalı bir kutu içinde epistemolojik olarak kurulmasının mümkün olmayacağı, dolayısıyla nesnelerin kendisinden ziyade nesnelerin arasındaki sonsuz değişkene sahip ilişkilerin dünyayı anlamada esas olduğu görüşü etkili olmuştur. Nihayetinde, aktör ağ kuramı farklı gerçekliklerin aynı anda yaratılabileceği, araştırmanın kendisi ve çıktısının eş zamanlı süreçlerle ilerlediği bir kuram ve yöntem olarak tarif edilmiştir.

Küresel güçlerle birlikte yerel dinamiklerin de küreselleşmeyi mümkün k1lan ve kolaylaştıran unsurlar olarak incelendiği bir dönemde, aktör ağ kuramı şehircilik alanında da dikkat çekmiştir. Yereldeki etkileşimleri açığa çıkarma hedefi, olayların karmaşık ve belirsiz çokunsurlu davranışlar olarak okunmasinı gerektirmektedir. Buna ek olarak, kent ve bölge algısının durgun bir olgudan ziyade, geçmiş, günümüz ve geleceğin içe içe geçtiği devinen ve evrilen bir olgu olarak görülmesi de karmaşıklık ve belirsizliği beraberinde getirmektedir. Bu noktada, aktör ağ kuramı karmaşık ve evrimsel süreçlerin anlık görüntüsünün alınmasında ön plana çıkmaktadır (Ruming, 2009, s. 458).

\section{Aktör Ağ Kuramındaki Temel Tartışmalar}

\section{Karmaşılklk ve Belirsizlik Düzleminde Pragmatist Bir Yaklaşım Olarak Aktör A ̆ Kuramı}

Aktör ağ kuramı sarmal oluşturan ağların analizinde pragmatist, yorumlayıcı ve etnografik yaklaşımları temel alan bir kuram ve yöntem sunmaktadır. Kent ve bölge gibi karmaşı olgulardaki ilişkileri anlama yollarının pragmatist ve artırımlı çerçevelerle ve ilişkilerin ampirik olarak gözlenebilir problemler doğrultusunda kurularak mümkün olduğu, dolayısıyla aktör ağ kuramının bu noktada anlamlı olduğu belirtilmiştir (Cvetinovic, Nedovic-Budic ve Bolay, 2017). Mekânsal ilişkilerin muhakeme ve temsilinde sarmalı oluşturan kurumlar arası karmaşık ilişkiler ve birliktelikler makro, mikro, küresel ya da yerel gibi herhangi bir kademe göstergesini içermeksizin ağ topolojisi ile ifade edilir (Murdoch, 1998). 


\section{Aktör A ̆g Kuramına İlişkin Kavramlar}

Heterojen Ortaklkklar ve Etkileşim Örüntüsü: İlişkileri ön planda tutan aktör ağ kuramı eylemin yalnızca insanlar arasında değil, insan olmayan bileşenler arasında, bu bileşenler sayesinde olduğunu kabul etmektedir. Aktörler ya da eyleyenler (actants) hayvanlar, nesneler, metinler, işaretler, olaylardan herhangi bir eylem ya da ilişki bağlamındaki kavramlara kadar çeşitlenmektedir (Latour, 2005, s.76). Dolayısıyla burada bileşenin tarif edilebilmesi için en önemli etken, o bileşenin ağ içerisinde varlık göstermesidir. Aktör ağ kuramına bağlı olarak yapılan yapılaştırma kuramı üzerine olan eleştiri (Murdoch, 1997; Ruming, 2008) bu noktada, toplumsal ve fiziksel/maddi bileşenlerin bir araya getirildiği heterojen ortaklıklar (heterogeneous associations) fikri ile anlam kazanmaktadır. Ağların yalnızca toplumsal bileşenlerden oluşması ve sürekli devam eden etkileşimlerden oluştuğu düşüncesi (I) yerelleştirmenin zorlaştıracağı için toplumsal ölçeklerin olmayışı ve (II) toplumun tekrar eden biçimde sürekli ve anlık olarak oluşturulmasıyla ortadan kalkan durağanlık ve kalıcıllğın imkansızlı̆g gibi problemleri de beraberinde getirmektedir (Murdoch, 1997). Dolayısıyla, toplumsal ve fizikselin birlikteliğinin zaman ve mekanın kontrolü ve düzeninde sürekliliği sağladığı savunulmaktadır. İnsan ve insanolmayan elemanların oluşturduğu heterojen ortaklıklar ağların (ya da kurumların) kapasite/etkileri (agency) hakkında bilgi verir.

Çeviri Süreci: Aktör ağ kuramı, aktörün ağ içindeki belirli şekildeki hareketini ve ağdaki etkileşim örüntüsüne referansla kendi terimlerini ve kavramlarını ortaya koyar. 'Çeviri' (translation) bu anlamda "aktörün müzakere edilme, kimliklerin tartışılma, rollerin paylaştırılma ve güç ilişkilerinin tayin edilme biçimine dair anahtar kavramlardan birini oluşturmaktadır" (Tait ve Jensen'den akt. Rydin, 2013). Çeviri süreci sorunsallaştırma (problematisation), ilgilenme (interessement), dahil etme (enrolment) ve harekete geçirme (mobilisation) aşamalarından oluşmaktadır (Rodger, Moore ve Newsome, 2009, s.648; Tait ve Jensen, 2007, s.112). Bu dört faz arasındaki ilişkiyi Rydin (2013, s. 26) şöyle açılamaktadır:

Sorunsallaştırma, kilit unsurunun bağlayıcı geçiş noktalarının (obligatory passage points) tanımlanmasıyla oluşan, sorunun çerçevelenme sürecidir. Bağlayıcı geçiş noktalarında, eyleyenler hakim problem çerçevesi kapsamında bir araya gelir ve yine bu problem bağlamında belirli müzakerelerde bulunurlar. Belirli eyleyen bu bağlayıcı geçiş noktasının tanımlanmasında ön plana çıkabilir ve ilgilenmenin (interessement) bi parçası olarak odak eyleyen (focal actant) durumuna gelirler. 
Dahil etme (enrolment) eyleyenlerin diğer eyleyenleri kendi ağ ilişkilerine dahil etmek amaciyla etkileme sürecine referans vermektedir (Rydin, 2013, s.26). Burada, 'aracılar' (intermediaries) eyleyenler arasındaki ilişkileri tanımlayan yazınsal ve teknik eserlerin, paranın ve yetenekleri ya da bilgisi sebebiyle insanların oluşturduğu çeşitli araçları tanımlayan bir kavramdır (Callon, 1990, ss. 135-140). Benzer şekilde, 'ortamcılar' (mediators) dahil etme aşamasında ağ topolojisini değiştiren bir unsur olarak tanımlanır (Cvetinovic vd., 2017, s.145).

Çeviri, durağan olmaktan ziyade, beklenmedik biçimlerde sürekli evrilen bir süreç olarak tanımlanmıştır (Ruming, 2008, s.10). Bu tanım, araştırmacının değişim ya da geçiş dönemlerinde aktörlerin çeviriyi nasıl stratejik biçimde kullandıklarını incelemesini zorunlu kılar. Çevirenin arzuları ya da aracıların değişim-eğilimli doğası çeviri sürecini devingen kılmakta ve sistem ya da sistemlerin nasıl evrildiğini gözlemlemek için geçmişin keşfini de gerektirmektedir.

\section{Kurumsallaşmayı Aktör A ̆ Kuramı Üzerinden Okumak}

Aktör ağ kuramı yazında teknik anlamda bir ağ ya da toplumsal anlamda bir kuram yerine çoğunlukla yöntemsel bir yaklaşım olarak ifade edilmiştir (Cvetinovic vd., 2017). Aktör ağ kuramı aktörlerin kendisinden yola çıkan bir yöntem olarak, aktörleri takip etmeyi, etkilerin izini sürmeyi ve sınırlı algılar dışındakileri egemen tanımayı gerektirir (Ruming, 2008, s.3).

\section{Evrimsel Kurumsallaşma Süreçlerinin İzini Sürmek için Yöntemsel Çerçeve}

Aktör ağ kuramını, farklı ölçeklerdeki planlama sistemlerinin araştırılmasında nitel bir yöntem olarak ele alan pek çok çalışma bulunmaktadır. (Boelens, 2011; Palmer, 2014; Rodger vd., 2009; Ruming, 2008; Ruming, 2009; Tait ve Jensen, 2007). Şimdiye kadar, aktör ağ kuramın heterojen ortaklıklar arasındaki ilişkileri ortaya çıkaran bir temel ve bu ilişkilerin oluştuğu, dengelendiği ve değiştiği mekanizmalar olarak ele alan çalısmalar planlama alanında kurumsallaşma süreçleri için genel bir çerçeve sunmaktadır. Kurumsal paradigmalar toplumsal normalleşme yoluyla değişime açık, dolayısıyla evrimsel olmaktadır (Salet, 2018). Dolayısıyla, kurumsal ilişkilerdeki belirli normalleşme ve denge anlarının, ilişkilerin devingen süreçler olarak kabul edildiği aktör ağlar üzerinden belirlenmesi kurumların nasıl evrildiğinin izini sürmeyi mümkün kılmaktadır. Bu noktada, aktör ağ kuramı, kurumsalcı düşüncenin benimsenerek, kurumsalcı araştırmanın yapılabileceği bir ortam da sunmaktadır. 


\section{Bölge Planlamanın Kurumsallaşma Süreçlerinin İncelenmesinde Aktör A $\breve{g}$} Kuramin Uygulamak

Gelişmekte olan aktör ağ kuramı yazınının, bu kuramın kavramsal bileşenlerini şehir planlama örnekleriyle operasyonelleştiren bir genel çerçeve sunduğunu yukarıda özetlenmiştir. Ayrıca, kurumsallaşma paradigmalarının evrimsel olması ve toplumsal normalleşme ile değişimlere açık olmasının kalıplaşmış kurumsal norm anlayışını değiştirdiğini, dolayısıyla belirli normalleşme ve denge anlarının aktör ağ görüntüsüyle bu dinamik sürecin takibinin mümkün olduğu da belirtilmiştir. Buradan yola çıkarak, aktör ağ kuramının bölge planlamanın kurumsallaşma süreçlerinin incelenmesinde bir düzlem oluşturduğu söylenebilir. Bu açıdan, (I) insan ve insan-olmayan bileşenlerle çoktürlü bölgesel birliklere işaret edilmesi, (II) bölgesel kurumların ağ topolojilerinin betimlenmesi, (III) bölge planlamada odak eyleyenlerin ve aracların izinin sürülmesi, (IV) aktörleri birbirine bağlayan bağlayıcı geçiş noktalarının vurgulanması, (V) kurumsallaşmadaki aşamaların ya da geçişlerin yakalanarak bütün bunların devingen bir süreç olarak ortaya konması mümkün olmaktadır.

\section{Heterojen Bölgesel Ortakliklar}

Bölge planlamanın kurumsallaşması yoğun olarak piyasa, uluslararası kurumlar, merkezi hükümet, yerel hükümetler, üniversiteler gibi kamu kurumları ve yurttaşları kapsayan çeşitli heterojen ortaklıkların sonucu olarak ortaya çıkmıştır. İnsan eyleyenler (human actants) plancılar, teknisyenler, politikacılar, bürokratlar, girişimciler, bakanlar, belediye başkanları, valiler, iş insanları, ve yurttaşlar olarak çeşitlilik gösterir. İnsan-olmayan eyleyenlerin toplumsalı dengede tutmayı ve ilişkileri zaman ve mesafeler ötesinde genişletmeyi mümkün kıldığı belirtilmiştir (Murdoch'dan akt. Ruming, 2008, s.5). Uluslararası ve ulusal örgütler, merkezi hükümet kurumları, finansal kurumlar, yerel ya da bölgesel kurumlar, akademi, özel sektör, sivil toplum kuruluşları, araştırma kurumları, bütçeler, planlar ve politikalar, kurumlar arası yazışmalar, araştırma ve analiz raporları, gelecek öngörüleri ve projeksiyonları, bölgesel planlama kuramları ve modelleri, tematik haritalar, nüfus piramitleri, planlama araçları, veri, yetenekler, sosyal sermaye, hesaplayıcılar, bilgisayarlar ve dahası bölgesel ortaklıların insan-olmayan eyleyenlerine örnek oluştururlar.

\section{Çeviri Yoluyla Bölgesel Kurumlarm Ă̆ Topolojisinin Oluşumu}

Ağ topolojilerinde rollerin ve güç dağılımının belirlenmesi ve etki alanlarının müzakere edilmesinde çeviri süreci ön plana çıkmaktadır. İlişkilerin dışa vurulduğu aktör ağın parçalarının bir araya getirilmesinde herhangi bir sırası ve düzeni olmaksızın belirli soruları sormak önemli olmaktadır. 
Hangi belirli odak eyleyenler dahil etme süreçlerinde bulunur ve temel dahil etme unsuru nedir sorularının araştırılması bağlayıcı geçiş noktalarının keşfedilmesini sağlamaktadır. Bütün kurumları örgütleyen baskın çerçeve zamanla değişim gösterebilmektedir. Örneğin, bölgesel eşitsizliklerin gidermeyi amaçlamak, bölgelerde inovasyon altyapısının kurulmasını hedeflemek ya da bazı bölgelerin ekonomik rekabet kapasitesini artırmak farklı dönemlerdeki bağlayıcı geçiş noktalarını oluşturuyor olabilir. Sadece belirli dönemlere özgü hedefler değil, aynı zamanda belirli normlar da bağlayıcı geçiş noktası özelliği kazanabilir. Rydin'in (2013, s.36) kentsel ölçekteki analizinde görülebileceği gibi planlama rıza süreci, bölgesel ölçekte de bakanlık, plancılar, girişimciler, yatırımcılar gibi toplumsal aktörleri örgütleyerek bağlayıc geçiş noktası olabilir. Daha öte bölgesel eyleyenler planlama bölgesi sinırları, yatırım alanları, altyapının ve sanayi gelişiminin fiziksel biçimini kapsayabilir.

Çevirinin eyleyeni/nesnesinin kim/ne olduğu, eyleyeni/öznesinin kim/ne olduğu ve hedef kitlesinin kim/ne olduğu kritik bir soru olarak araştırmacının karşısına çıkmaktadır. Örneğin, merkezi hükümet kurumları, uluslararası kurumları, yabancı danışmanları ve fonlama mekanizmalarını bölgesel plan ve program yapımında çeviri sürecine dahil edebilir. Bu sorunun tartışılması aynı zamanda odak eyleyenlerin belirlenmesini de sağlayabilir. Bölgesel planlama ya da politika üretimi dahilindeki her kurumsal süreç çeviri bağlantıları diğer aktörlerden daha sık olan odak eyleyenler etrafında başlatılır. Kurumsal süreçte kurumların ve normların sebebiyle farklı ă topolojileri sunan bir çok evre olabileceği için odak eyleyen ya da eyleyenler bu süreç içinde farklılaşabilir. Değişen odak eyleyenler aynı zamanda aktör ağındaki değişen güç ilişkileri ve güç dengelerine işaret eder. Örneğin, denetim kurul ya da komiteleri pek çok kurum için onay odak aktörünü oluştururken, bakanlıklar politika oluşturmanın, devlet örgütleri plan yağımı ya da bütçe oluşturmanın odak aktörü konumunda olabilirler.

Eyleyenler arasındaki ilişkileri ve ilişkilerin biçimlerini tanımlayan aracılar (intermediaries) bir diğer harekete geçirici soruyu oluşturmaktadır. Bölgesel kurumsallaşma süreçleri kapsamında bölgesel planlar ve politika belgeleri aracı konumundaki en temel eserleri oluşturmaktadır. Ulusal Kalkınma Planları, Bölgesel Kalkınma Ulusal Stratejileri ve kurumların kuruluş kanunları etkileşimlerin aracıları olarak işlev görürler.

Bu noktada, aracıların değişimiyle çeviri süreçlerinin nasıl değiştiği arasındaki bağı çözümlemek araştırmacıya kurumsallaşma sürecindeki dönüm noktalarını izini sürme, kurumsallaşmadaki farklı evreleri farklı ağ örüntüleriyle ortaya koyabilme ve bu evrelerdeki odak eyleyenlere işaret edebilme firsatını 
vermektedir. Örneğin, bir uluslararası yaptırım sonucu ya da iç rejimin değişmesi sonucu önceki aracıları geçersiz kılan yeni aracılar tanımlanabilir. Bu durumda, heterojen ortaklıkların bileşenleri değişim yaşayabilir, yeni bağlayıcı geçiş noktaları tanımlanabilir ve çevirileri alternatif ağ topolojileri oluşturan yeni odak eyleyenler ortaya çıkabilir. Aktör ağlardaki bu değişimlerin izini sürmek araştırmaciya aynı zamanda çıkarımlar yapma, genel bir çerçeve oluşturma ve eksik mekanizma ve eyleyenlere işaret etme firsatını verir.

\section{Türkiyedeki Bölge Planlamanın Kurumsallaşma Süreçlerini Aktör A Kuramıla Okumak}

\section{Kurumsallaşma Sürecindeki Değişen Bağlayıcı Geçiş Noktalarn}

Türkiye'de bölgesel planlama pratiğinin kurumsallaşma sürecinde bağlayıcı geçiş noktalarının üç kaynağı olduğu söylenebilir. Toplumsal aktörleri kaynaştıran ve ağdaki bağlantıları kuran geçiş noktalarından biri planlama rıza süreci (planning consent process) olarak tanımlanabilir. Bölgesel planlamanın, eyleyenlerin alt ağlarındaki müzakereler yoluyla gerçekleşmesi hedeflenmiştir. Burada, müzakerelerin ortak noktasın bölgesel kalkınmanın temel hedefleri oluşturmuştur. Yirminci yüzyılın ilk yarısına kadar sanayi gelişimdeki kamu yatırımları ve gerekli altyapının temini bağlayıcı geçiş noktasını oluşturmuştur. 1960 sonrasında ise bölgesel kalkınmanın hedefi bölge kalkınma planları yoluyla sektörel ve mekânsal kalkınmanın eş zamanlı olarak gelişmesi olmuştur. $\mathrm{Bu}$ anlamda, bölgesel gelişme politika ve stratejileri kaynakların etkili kullanımı, ulusal ekonomik büyüme, bölgesel eşitsizliklerin giderilmesi, kentleşme süreçlerinin yönlendirilmesi ve kontrol edilmesi ve altyapı gelişiminin sağlanması bölge planlarının odağını ve aktör ağ kompozisyonunu tanımlamıştır.

3194 sayılı İmar Kanunu'nun yürürlüğe girmesiyle, 1985'te, planlama rıza sürecine dayandırılan bağlayıcı geçiş noktası değişmiş ve "planların kademeli birlikteliği ilkesi" yeni geçiş noktasını oluşturmuştur (Ersoy, 2006, s.224-225; Sert, 2012, s.107). Bu ilke, bölgesel kalkınma planlarının, mekânsal strateji planları, çevre düzenleme planları ve gelişme planları gibi daha alt kademedeki planlara dayanak oluşturması gerektiğini ortaya koyar. Dolayısıyla bu kanunun yürürlüğe girmesiyle birlikte Bölge Kalkınma İdareleri/Birlikleri, Devlet Planlama Teşkilatı (DPT) ve İmar ve İskan Bakanlığı gibi resmi kurumlar arasında bağların oluşmasını sağlayan yeni bir bağlayıcı geçiş noktası oluşmuştur. İmar Kanunu bu açıdan kurumlar arası ilişkilerin kurulmasını mümkün kılan temel aracilardan biri olmuştur.

Avrupa Birliği müzakereleriyle başlayan süreçte, bölge ölçeğinde etkin olan bir kurumun oluşması gerekli görülmüştür (Akgül ve Efe, 2010, s.67; Çalt, 2005, 
s. 12; Serin, 2006, s.63). Bu noktada, DPT bünyesinde bölge tanımında ekonomik gelişmişlik düzeyi ve uluslararası veri tabanına uygunluk esas alınarak yeni kurumsal düzenlemeler gündeme gelmiş ve Bölgesel Kalkınma Ajansları (BKA) kurulmuştur (Akgül ve Efe, 2010, s.67; Arslan ve Demirel, 2010, s.52). Bu anlamda, Avrupa Birliği Müktesebatını Üstlenilmesine İlişkin Türkiye Ulusal Programlar'ını 2006 yılında Kalkınma Ajansları Genel Müdürlüğü'nün kurulması için en etkin aracı olarak görmek mümkündür. BKA'nın yetki ve görev tanımları stratejik bölgesel planlar hazırlamak üzere düzenlenmiştir. 2018'de 3194 sayılı İmar Kanunu'nun 6. maddesinde yapılan değişiklikle birlikte planların kademeli birlikteliği ilkesi dahilinde Çevre ve Şehircilik Bakanlığı'nın hazırladığı Mekânsal Strateji Planları çerçevesinde, "Çevre Düzeni Planları" ve "İmar Planları" kademe sistemini oluşturmuş, BKA tarafından hazırlanan "Bölge Planları" mekânsal kademe sisteminden çıkarılmış ve planlama hedefleri açısından bir tavsiye dökümanı niteliği kazanmıştır. Buna paralel olarak, farklı kurumlar tarafindan hazırlanan bölge planlarının sektörel ve mekânsal odakları birbirinden farklılaşmaya başlamıştır (Köroğlu, 2012, s.4). Aktör ağın bir tarafında bölgesel ekonomilerin kapasitelerinin artırımı ve bölgesel rekabetin artırılması hedeflenmiş, öte tarafinda ise kentsel gelişime yön vermek, kontrol etmek ve müdahale etmek temel amaç haline gelmiştir. Pek çok farklı kurumun bölge ölçeğinde planlar hazırlamasıyla birlikte bağlayı geçiş noktası bir kez daha, bu sefer müzakereye daha az yer vererek, planlama riza sürecine doğru kaymıştır. Bu üç evreyle birlikte, değişen araciların farklı bağlayı̊ geçiş noktaları oluşturma üzerindeki etkisini gözlemlemek mümkündür.

\section{Bölge Planlama Ağ Topolojisindeki Değişen Odak Eyleyenler}

\section{0-2011 I Özerk Denetim Mekanizmaları ve Temel Odak Eyleyen Olarak DPT}

Kurumsallaşma sürecindeki odaksallıklar zaman içinde dört ayrı etkileşim örüntüsü sergilemekte, bu durum bölgesel planlama ağlarındaki odak eyleyenlerin devingenliğine işaret etmektedir. Kurumsal aktör ağların ilk evresi iki aşamadan oluşmaktadır. İlk kurumsallaşma evresinin ilk aşaması bölgesel planlamanın bir disiplin ve pratik olarak ortaya çıktığı, dolayısıyla, bölgesel planlamanın merkez kurumlarının oluşturulduğu zamanı kapsamaktadır. İlk evrenin ikinci aşaması ise bölgesel politikalar ve pratikleri bünyesinde barınd1ran yerel kurumların oluşturulduğu dönemi kapsamaktadır. Kurumsal kimliklerin oluştuğu ve rollerin müzakere edildiği ilk evreyi takip eden iki evrede 
ise yetki ve görevlerin transferi ya da bazı kurumların diğerlerinin organizasyon şemasına eklemlenmesiyle kurumsal kademelenmenin değişmesi söz konusu olmaktadır.

İlk evreyi betimleyen ilk ağ topolojisinde, DPT (1960-2011), İmar ve İskan Bakanlığı ve sonrasında Bayındırlık ve İskan Bakanlığı bölgesel planlama ağlarındaki odak eyleyenleri oluşturmuşlardır (Özyurt, 2012, s.456). (Şekil 2). Burada DPT'nin çeviri sürecinde uluslararası fonlama mekanizmalarını ve danışmanları plan yapımı sürecine dahil ettiği (enrolment) görülebilir. DPT tarafından hazırlanan Ulusal Kalkınma Planları ve Programları bölgesel planlama ihtiyacına işaret etmiş ve bu ölçekteki planlama kapsamının belirlenmesinde üst çerçeveyi çizmeye yardımcı olmuştur (Arslan, 2005, s. 280; Özyurt, 2012, s. 460461). Dolayısıyla, ulusal ölçekteki kalkınma planları ve politikalar, bu planların yerel düzeyde yansımaları olması beklenen bölge planlarının oluşturulmasında aracılar olarak görülebilir. Benzer şekilde, İmar ve İskan Bakanlığı'nın özellikle Antalya Bölge Planı hazırlanmasında Birleşmiş Milletler Gıda ve Tarım Örgütü'yle olan koordinasyonu gibi farklı dahil etme süreçleri ve mekanizmaları gözlenebilir (Mutlu, 2008, s. 3; Özyurt, 2012, s.458). Bu evredeki çeviri pratikleri bölge planlama çalışmalarında çeşitli kurumlar arasındaki iş birliğine işaret etmektedir.

İlk evrenin ikinci aşamasında Planlama Yüksek Kurulu (PYK), Bölgesel Gelişme Yüksek Kurulu (BGYK) ve ona bağlı olarak Bölgesel Gelişme Komitesi bakanlık üzerinde işlerlik gösteren özerk denetim mekanizmaları sistemin odak eyleyenlerini oluşturmuştur (Şekil 3). PYK ve BGYK'nın sistem içinde yeni ilişkiler tanımlaması ve odaksallıklarını artırması koordinasyon, bütçeleme ve politika belgeleri üretme gibi aracllar üzerinden gerçekleşmiştir. Bu aşama bölgesel yönetimlerin oluşumları yoluyla yerel gündemlerin kurumsallaşmaya entegrasyonuna yönelik bir girişime işaret etmektedir. Kalkınma Ajansları Genel Müdürlüğü (KAGM) ve Bölgesel Kalkınma İdareleri (BKİ), bu açıdan, yeni oluşan bölgesel eyleyenler olmuşlardır. Bu eyleyenler aynı zamanda odak eyleyenleri vurgulayan ikinci derece alt ağları oluşturmuştur. $\mathrm{Bu}$ anlamda, DPT'nin odak eyleyen olarak merkeziliği, KAGM ve BKİ alt ağında vurgulanmaktadır (Leblebici ve Erkul, 2008).

Bu aşama aynı zamanda çeşitli çeviri süreçlerine de referans vermektedir. Kalkınma Ajansları Genel Müdürlüğü'nün belediyeler, Sanayi ve Ticaret Odaları ve Avrupa Birliği'ni aktör ağda eyleyen olmak üzere sürece dahil ettiği görülmektedir. Benzer şekilde, Bayındırlık ve İmar Bakanlığı, GAP, DAP, DOKAP gibi projeler kapsamında Bölge Kalkınma İdareleri'ni dahil etmiştir. Çeviri süreci yalnızca tek yönlü değil, ortak tanımlanmış hedefe yönelik olarak 
bütün eyleyenlerin birbirini dahil etmesi şeklinde de gerçekleşebilir. Bu anlamda, Yeşilırmak Havza Gelişim Projesi kapsamında valilikler ve Yeşilırmak Havzası İ Özel İdareleri Hizmet Birliği'nin (2004 sonrası Yeşilırmak Havzası Kalkınma Birliği) içinde bulunduğu çeviri süreci bu duruma örnek oluşturmaktadır (Tutar ve Öztürk, 2010, s. 11).

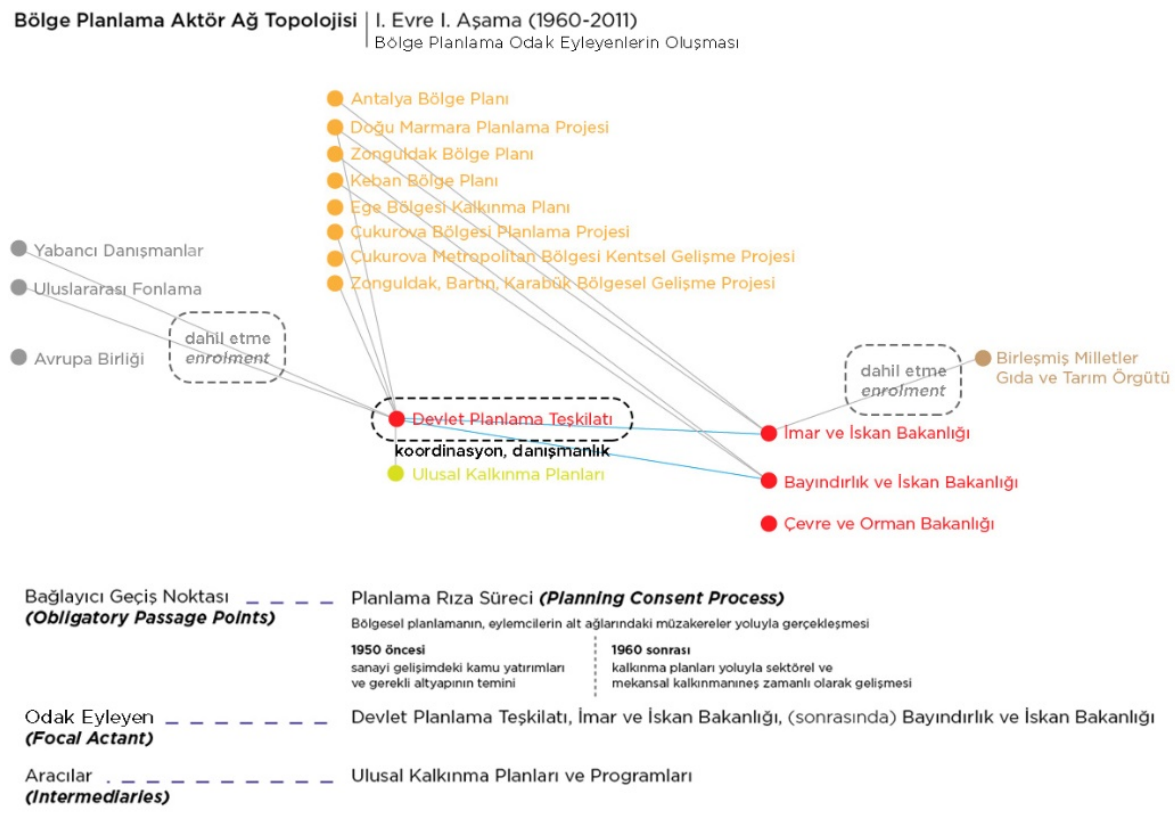

Şekil 2: Türkiye' de bölgesel planlamanın kurumsallaşma sürecinde birinci evrenin ilk aşamasının aktör ağ topolojisi 


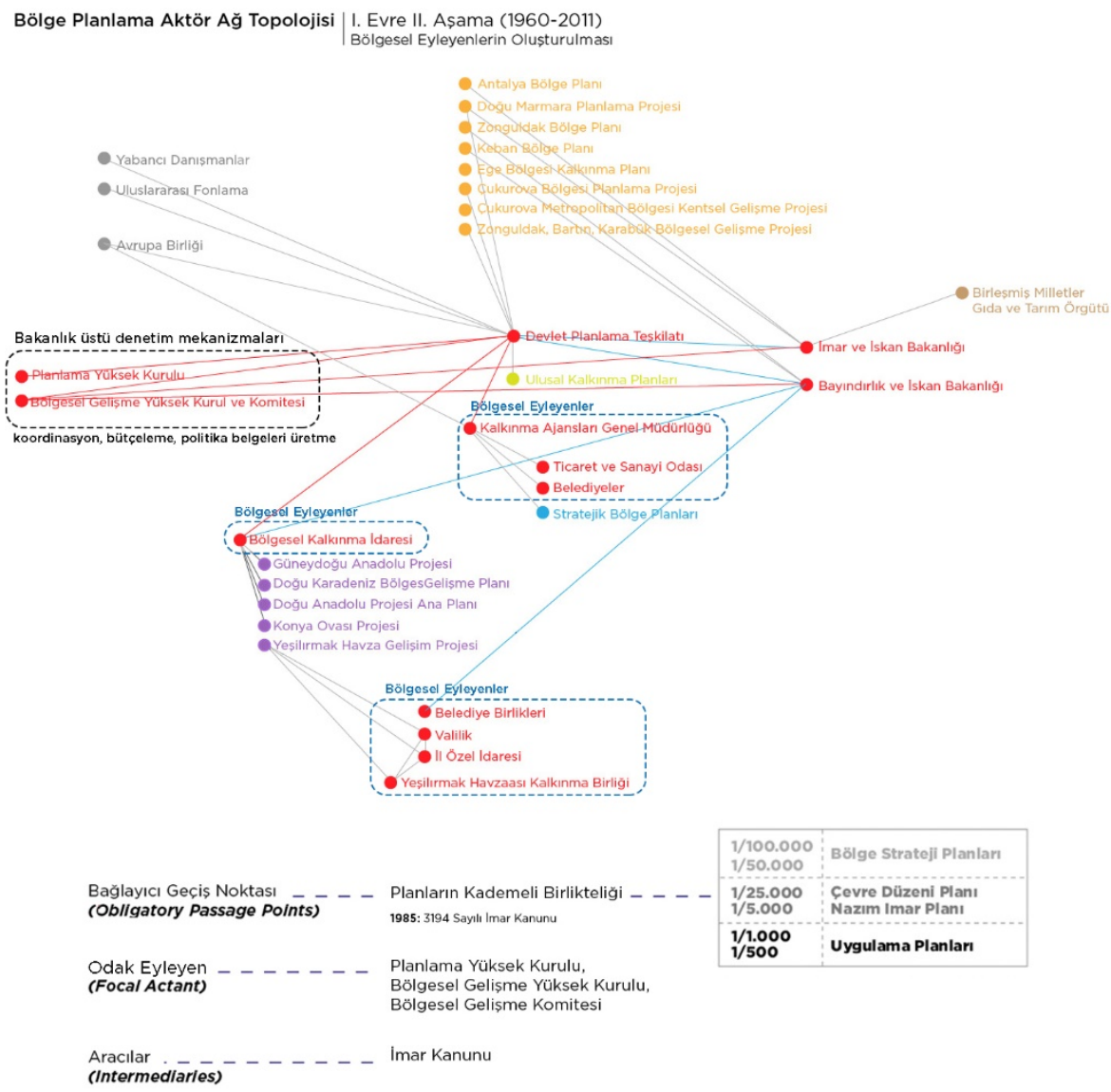

Şekil 3: Türkiye'de bölgesel planlamanın kurumsallaşma sürecinde birinci evrenin ikinci aşamasının aktör ağ topolojisi

2011-2018। Temel Odak Eyleyen Olarak Kalkınma Bakanlı̆̆ı ve Avrupa Birliği Bakanlığının Öne Çıkması

DPT'nin görev ve yetkilerinin Kalkınma Bakanlığı'na (2011-2018) transferiyle birlikte (Derdiman, 2015; Fedai, 2016, s. 417; Köroğlu, 2012, s. 3) ağ topolojisi farklı bir örüntü oluşturur (Şekil 4). Kalkınma Ajansları Genel Müdürlüğü, Bölge Kalkınma İdareleri, Planlama Yüksek Kurulu ve Bölgesel Gelişme Yüksek Kurulu'nun Kalkınma Bakanlığı altında işlerlik kazanması, bu bakanlığın aktör ağdaki ortaya çıkan odak eyleyen olduğunu göstermektedir. Benzer şekilde, Çevre ve Şehircilik Bakanlığı (2011-...) bölgesel sınırları kapsayan planlar yapma sorumluluğu bulunan bir kurum olarak bu ağın odak eyleyeni konumuna gelmiştir. 
Bu aşamada, Kalkınma Ajansları tarafından hazırlanan Stratejik Bölge Planlarının sektörel, Çevre ve Şehircilik Bakanlığı tarafından hazırlanan Stratejik Mekânsal Planlar ve Çevre Planları gibi diğer bölgesel planların ise mekânsal olarak kategorik olarak ayrışması (Köroğlu, 2012, s. 4), Kalkınma Ajansları tarafindan hazırlanan planlar ve diğer kurumlar tarafından hazırlanan bölge planları arasında bir tutarsızlık sorunu ortaya çıkarmaktadır. Ayrıca, stratejik bölge planlarının, kademeli birliktelik ilkesi doğrultusunda yalnızca bir tavsiye dökümanı niteliği olması sebebiyle Kalkınma Ajansları tarafından hazırlanan bu planların uygulamaya yönelik olmadığı görülmektedir.

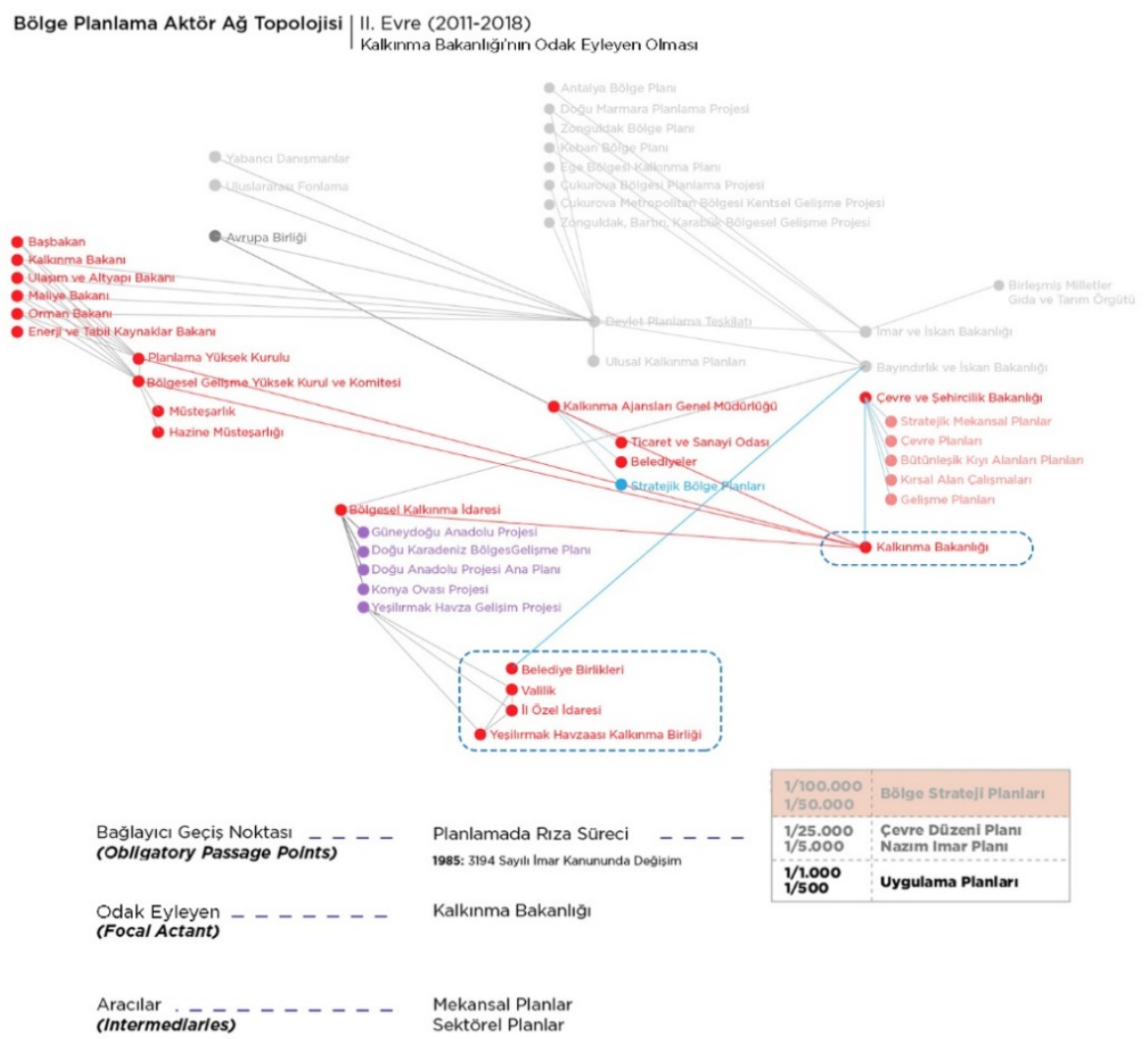

Şekil 4: Türkiye' de bölgesel planlamanın kurumsallaşma sürecinde ikinci evrenin aktör ağ topolojisi

2018-... I Başkanlık ve İlgili Kurumlarm Mutlak Denetim Mekanizması olarak Ortaya Çıkışı

Kalkınma Bakanlığı'nın kaldırılmasıyla birlikte bölgesel kurumları kendi bünyesine katan Sanayi ve Teknoloji Bakanlığı ağın yeni odak eyleyeni olarak 
ön plana çkmaktadır. Bu yeni aktör ağında Cumhurbaşkanlığı Strateji ve Bütçe Ofisi (2018-...) de Ulusal Kalkınma Plan ve Projelerinin hazırlanması görevinin bu kuruma transferiyle yeni oluşan bir diğer odak eyleyeni oluşturur.

2018'de yürürlüğe giren 703 sayılı Kanun Hükmünde Kararname ile Yüksek Planlama Kurulu ve Bölge Gelişim Yüksek Komitesi' nin görev ve yetkilerinin yeni oluşan kurumlara, odak eyleyenlere, transferiyle birlikte aktör ağındaki ilişkiler yeniden kurulmuş ve aktör ağ topolojisi büyük oranda değişmiştir (Şekil 5). Bu bağlamda, Planlama Yüksek Kurulu'nun yetkileri Cumhurbaşkanlığı Ekonomi Politikaları Kurulu, Cumhurbaşkanlığı Politika Kurulu, Cumhurbaşkanı, Hazine ve Ekonomi Bakanlığı ve bağlı kurumlara transfer edilmiştir. Ayrıca, Bölgesel Gelişme Yüksek Kurulu'nun görevleri Cumhurbaşkanlığı ve Sanayi ve Teknoloji Bakanlığına, Bölgesel Gelişme Komitesi'nin görevleri ise Cumhurbaşkanlığı Ekonomi Politikaları Kurulu ile Sanayi ve Teknoloji Bakanlığı'na transfer edilmiştir. Kısaca, aktör ağ topolojisinin son evresi Cumhurbaşkanlığına bağlı kurumların odak eyleyen olarak egemen olduğu, özerk denetim mekanizmalarının görülmediği bir aktör ağ topolojisi sunmaktadır.

Geniş bir açıdan bakıldığında, ortaklıkların oluşumu ve süreç içindeki dönüşümü 2000'ler sonrasında aktör ağlarındaki odak eyleyenlerin hızlı değişimini göstermektedir. Daha önemlisi, başlangıçta kurulan denetim mekanizmaları ağ içinde ciddi bir değişimle karşı karşıya kalmıştır. İlk evre, odak eyleyenlerin denetim, koordinasyon, iş birliği, bütçeleme ve genel bir bölgesel politika çerçevesi oluşturma gibi görevleri üstlenen özerk kurumlar (örneğin BGYK) ve koordinasyon sağlama ve danışmanlık hizmeti verme yoluyla merkezi hükümete yardımc pozisyona sahip kurumsal yapıda bağımsız konumlanan ajansların (başlıca DPT) olduğu bir tablo sunmaktadır. İkinci evrede ise önceki özerk kurumların merkezi hükümet kurumlarının altında yer almasıyla ve denetim görevinin merkezi hükümete transferiyle Kalkınma Bakanlığı gibi merkez kurumların odak eyleyen olduğu görülmektedir. Üçüncü evre ise cumhurbaşkanlı̆̆ altındaki kurumlarının bölgesel planlama otoriteleri üzerinde egemenlik kurduğu bir örüntüyü yansttmaktadır.

Bu evrede gözlenen kurumsal yapı çerçevesinde bölge planlama pratiği incelendiğinde, hazırlanan bölge planlarında katılımcı sürecin ihmal edilmesi sonucu, planların istenen düzeyde başarıya ulaşmadığı ve bazı durumlarda toplum tarafından kabul görmediği ortaya çıkmaktadır. Katılımcı ve agonistik bir sürecin sağlanmadığı ortamda karşıt görüşler yok sayılmakta ve hatta farklı görüşlere sahip aktörlerin kurumsallaşmada rol almadığı gözlemlenmektedir. İkinci evrede, Bölgesel Gelişme Komitesi (BGK) özerk bir kurum olarak, farklı paydaşları bir araya getirmeyi amaçlasa da kurumun amacı doğrultusunda 
farklı paydaşlar için agonistik bir çekişme ortamı oluşturma şansını kullanmadığını görmüştük. Bununla birlikte 2018'de BGK'nin feshedilmesi ve yetkilerinin devredilmesi bu savı desteklemektedir. Katılımcı bir sürecin işlemediği bu ortamda agonistik bir kurumsallaşmaya olan ihtiyaç çeşitli bölge planlarına ve projelerine karşı, yerel halk tarafından çevre ile ilgili konularda yapılan protestolar ve gösterilerde gözlemlenmektedir.

Bölge Planlama Aktör Ağ Topolojisi $\mid$ III. Evre (2018-...)

Cumhurbașkanlığı Kurumlarının Odak Eyleyen OIması

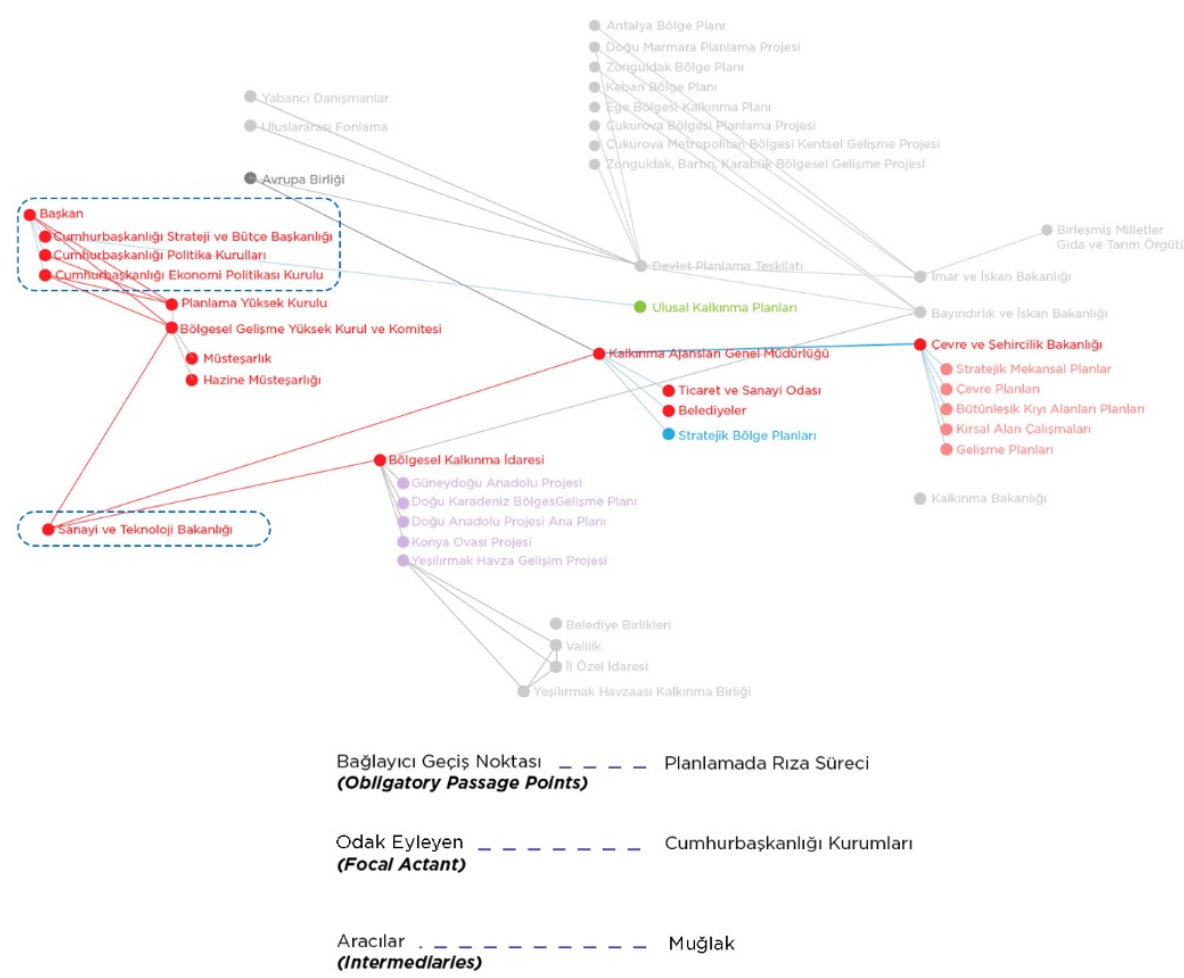

Şekil 5: Türkiye'de bölgesel planlamanın kurumsallaşma sürecinde üçüncü evrenin aktör ağ topolojisi

\section{Agonistik Demokrasi Kuramına Genel Bakış}

Agonizm kavramının ortaya çıkmasındaki en büyük etken günümüzde operasyonel kolaylıklarından dolayı sıkça başvurulan araçsal rasyonaliteye dayalı planlama ve işbirlikçi (müzakereci) planlama modellerinin neo-liberal gündemle birlikte oluşan birçok koşula yanıt vermemesi, artan eşitsizliklere ve post-politik durum içinde ayrışmalara yol açmasıdır. İçinde bulunduğumuz 
mevcut durum demokraside açığa ve güven kaybına yol açarken, vatandaşlar tarafından içselleştirilmemiş proje ve politikaların artışını da gözler önüne sermektedir. Politik bir kuram olarak ortaya çıkn agonistik demokrasi, günümüzde sıkça başvurulan müzakereci teoriler ve tutumlar aksine karşıt görüşlere ve bu görüşler arasındaki çekişmelere vurgu yapar. Böylece mutabakata ulaşmayı amaçlayan yaklaşımlar yerini, fikir ayrılıklarına bırakır; anlaşmazlıklar ve çekişmeleri gidermek yerine, bunları odağına alan çoğulcu bir bakış açısına imkan sağlanır.

Makalenin bu bölümünde agonistik çoğulculuk teorisinin planlama gündemindeki yansımalarına odaklanırken, karar verme süreçlerinde agonistik düşüncenin dayandığı "çekişme" kavramının benimsenmesi ile kurumsal düzeyde ortaya çıkan etkiler ve kurumsallaşmanın sağlanmasında çoğulcu bakış açısının Türkiye'de bölge planlamanın kurumsallaşmasına nasıl etki edebileceği ele alınmıştır.

\section{Uzlaşmacı Demokrasinin Yerine Çekişmeleri Odağına Alan Bir Kurama Doğru}

Hâlihazırda mevcut bulunan müzakereci ve işbirlikçi teorinin uzlaşmaya dayalı yaklaşımını reddeden agonizm; çekişmelere, demokratik tartı̧malara ve karşıt görüşlere odaklanır (Lowndes ve Paxton, 2018; Mouffe, 1999). Agonistik yaklaşımın yükselişinin ardında yatan asıl neden daha demokratik bir duruma ulaşma amaciyla siyasal tartışma ortamını ve içinde yer alan karşıt fikirlere yaklaşımı düzenlemektir. Bu bağlamda Chantal Mouffe (1999) agonistik demokrasi kuramının gerekçelendirmesini, uzlaşmacı demokrasinin karşıt grupların siyasi ve kolektif kimliğini tanımakta eksik kalmasıyla açılamaktadır. Bäcklund ve Mäntysalo (2010) rasyonalite veya müzakereci anlayışa dayalı karar verme mekanizmalarının ortak fikir oluşturma ve karşılıklı çıkar düzenlemesine dayandığını belirtirken, Mouffe (2013) post-politik bir durum olarak tanımladığı, müzakere ve uzlaşma ile ortaya konan sistemin "depolizasyona ve siyasi bir nötrleşmeye" yol açt̆ğının altını çizer. Mouffe (1999; 2013) siyasi aktiviteyi "hiç bitmeyen bir mücadele" olarak kabul eder, bu yüzden uzlaşma bu süreci öldürecek ve her iki tarafın da iddialarını, bakış açısını ve kimliğini kaybettiği siyasi sonrası bir duruma yol açacaktır. Chantal Mouffe'un ortaya koyduğu agonistik demokrasi ile farklı ve karşıt siyasi kültürlerin birbirini tanımasının önemi vurgulanırken, bununla birlikte gelen çekişme ortamı her iki karşıt tarafın bir arada var olabilmesinin önünü açacaktır (Martin, 2013; Pløger, 2004). Bu politik çoğulculuk ancak karşılıklı anlayış ve karşıdakinin düşüncesini tanıma ile mümkündür. 


\section{Karşıt Görüşlerin Meşruluğu}

John Rawls ve Jürgen Habermas'in demokratik toplumun temelini fikir birliği yaratmaya dayandığı görüşü, Mouffe (2013)'a göre ancak bireylerin ve toplulukların kendi çıkarlarını bir kenara bırakması ile mümkündür. Fikir birliği yaratma ideali bireyleri kendi düşüncelerinden ve kimliklerinden ayırmaktadır. İnsanı özgürleştirmek için, demokratik çekişmelerin ortaya çıkma olasılığına her zaman açık olmak gereklidir; ancak bu sayede farklılıklar karşı karşıya gelebilir ve çekişen bu taraflar arasında anlayışa dayalı bir ilişki bütünü oluşabilir. Demokratik süreç bu çekişmenin gerçekleşeceği ortamı sağlamakla yükümlüdür (Mouffe, 2013; Wenman, 2003).

Bu noktada agonizm kavramında bahsedilen çekişme ve çatışmaların antagonizm yaratacak bir negatif anlam barındırmadığına dikkat çekmek gerekir. Aksine agonizm antagonizmin oluşmasını engellemek için bu çekişmeleri araç olarak kullanır. Carl Schmitt' in karşıtlık (antagonizm, düşmanlık) kavramsallaştırması karşıt tarafların varlığını kabul ederken, agonizmden ayrı, karşıtlığı ön plana alan bir bakış açısı sergilemektedir (Roskamm, 2015). Schmitt' in ortaya koyduğu dost ve düşman kavramlarıyla ikili yargılar üzerinden açıkladığı toplumsal sistemde birbiriyle çelişen görüşler "öteki", "muhalif" veya "yabancı" kategorilerine bürünürler (Mouffe, 1999; Roskamm, 2015). Bu karşıtlık bireylerin ve toplulukların birbirinden ayrışmasına ve uzaklaşmasına neden olur. Bu bağlamda, karşıtlık (antagonizm) kavramı karşılıklı çatışmanın olumsuz ve düşmanca çağrışımlarına odaklanır. Mouffe (2005) antagonizm kavramını agonistik çoğulculuğu açıklamak için bir temel olarak alırken; agonizmi ehlileştirilmiş antagonizme benzetir. Ortaya çıkan çekişme ve çatışmalar ne kadar fikir birliğini mümkün kılmasa da muhalif tarafların meşruluğunu tanıyacak ilişki örgüleri ortaya çıkarmaktadır. Bu sayede Schmitt'in "öteki" tanımı düşman olarak algılanmaktan ziyade, bir rakip olarak kabul görür.

Agonizmin odak noktası, rasyonel bir fikir birliğinin mümkün olmadığı; bunun yerine antagonizm koşuluyla başa çkmak için yeni bir mekanizmanın tanımlanması gerekliliğidir. Demokrasinin temel görevi "insan ilişkilerinde var olan potansiyel karşıtlığı etkisiz hale getirmek" ve karşı görüşlerin meşruluğunu kabul ederek, bu karşıt anlayışların yol açabileceği çatışmaları antagonizme yol açmadan, agonizme dönüştürmektir (Roskamm, 2015, s. 385). Bu anlamda agonizm uzlaşı yoluyla çatışmayı ortadan kaldırmaya da çalışmaz. Aksine çoğulculuğa açık, çeşitliliği kabul eden, demokratik topluluğu teşvik eden ve karşıt görüşler arasındaki boşluğu dolduracak üretken ve yenilikçi bir gerilim yaratmayı amaçlamaktadır (Lowndes ve Paxton, 2018; McAuliffe ve Rogers, 2019). 


\section{Agonistik Temellere Dayalı Bir Kurumsallaşma}

\section{Çekişme, Olumsallık (Contingency) ve Karşılıkh Bağhlık (Interdependence)}

Agonizm fikri söylem, çekişme ve esnekliği teşvik etme bağlamında tartı̧̧lırken; agonistik demokrasiler, demokratik çekişmeye dayalı yapıcı söylemi merkezine alır. Bu odağın arkasındaki ana sorunsal, çeşitliliğin fazla olduğu çoğulcu topluluklarda büyük ölçüde fikir birliğine dayanan müzakereci demokrasinin pratikliği ve sürdürülebilirliğine karşı bir şüphedir. Agonistik demokrasi, demokratik çekişmenin kurucu ve potansiyel olarak yapıcı doğasını vurgular (McClymont, 2011). Bunu başarmak için Mouffe (2005), çekişmenin tanınması aracilığıyla karşıtlıkların kurumlar içinde verimli olabileceğini savunur.

Lowndes ve Paxton (2018, s. 695)'a göre agonistik demokrasilerin "çekişme (contestation)", "olumsallık (contingency)" ve "karşlıklı bağlılık (interdependence)" olmak üzere üç ön koşulu mevcuttur. Çekişme ön koşulunun beraberinde yapıcı söylemi ve yenilikçiliği getirmesi beklenir. Çekişmenin olmadığı toplumlarda, katılım azalmakta ve vatandaşlar arasında siyasal ilgisizlik artmaktadır. Çekişmenin mevcudiyeti sadece agonistler tarafından siyasal kimliklerin oluşması için önemli olarak algılanmakla kalmaz, aynı zamanda kişilerin kimliklerinin (identity) yaratılması için de gereklidir.

Benzer şekilde agonistler, toplumsal değerleri tartışmaya ve çekişmeye açık olarak gördükleri için evrensel doğru, tarafsızlık ve rasyonalite iddiaların reddederler (Lowndes ve Paxton, 2018). Agonist bakış açısı çoğulcu bir toplumda, bir grubun doğru ve tartşılamaz söyleme ve değerlere sahip olduğu iddiasını, yeni kavramlar ve anlatıların çoğulluğunu önlenecek bir durum olarak yorumlamaktadır. Bu anlamda, olumsallık anlayışı (contingency) demokratik dışlanmanun üstesinden gelmek ve çoğulculuğu desteklemek için temeldir. Olumsallık, tüm baskın güç iradelerinin tartşslabilmesine olanak tanırken, denetleme ve eleştiri için bir sahne oluşturur.

Karşlıklı bağllık (interdependence), kişilerin bireyselliklerini ve kimliklerini kendi topluluklarının diğer üyeleriyle ilişki ve karşıtlık içinde geliştirdiği fikrini ortaya atar (McAuliffe ve Rogers, 2019). Bu anlamda, agonistler için kimlik kavramı toplumlarının diğer üyelerinin ilkeleri ve değerleri ile çekişmeler sonucu karşllıklı bağlllık üzerine kurulu ilkeler ve fikirler koleksiyonudur. Bir demokraside tüm vatandaşlar zorunlu olarak birbirine bağlıdır. Bu ilişkiler bü- 
tünü bir grubun hakimiyetini denetlemek ve hâkim güç ilişkisine meydan okumak için, siyasi katılımda yer alan birbirine bağlı gruplardan oluşan karmaşık bir ağın temel olduğunu öne sürer (Lowndes ve Paxton, 2018).

Agonizmin bu üç ana önkoşulunun, katılımc siyasal aktörler olarak vatandaşların yaratıcı ve birbirine bağlı doğasını canlandırma kapasitesi vardır. Demokratik çekişmeyi canlandırmak ve oluşabilecek antagonizminüstesinden gelmek; ancak agonizmin karar alma süreçlerinin kurumsallaşmasına nüfuz etmesi ile mümkündür.

\section{Olumsallĭga Dayanan Agonizm ve Düzene Dayah Kurumsallaşma Nasıl Bir Ortak Değerde Buluşabilir?}

Lowndes ve Paxton (2018) kurumsallaşma ve agonizm bir arada ele alınırken ortaya çıkan çelişkiyi incelemişlerdir ve bu çelişkinin nasıl giderilebileceği üzerine spekülasyonlarda bulunmaktadırlar. Bu çelişkinin temelinde yatan sebep ise günümüzde kurumsallaşmanın ortak değerlere dayanan akılcı tutum ve örgütsel düzenlemeler üzerinden inşa edilmesi; agonizm bakış açısının ise olumsallığa (contingency) ve fikirlerin tartışlmasına dayanan tutumu olarak açıklanabilir. Günümüzün karar alma sürecinde, kurumlar istikrar ve öngörülebilirlik oluşturan yapılar olarak görülmekte ve "siyasette düzen ve düzenliliğin temelleri" olarak kabul edilmektedir (Skowronek, 1995). Temsili demokrasilerde kurumlar menfaat ilişkilerini organize etmeyi amaçlar. Bu çerçevenin oluşturduğu uzlaşma süreçlerinde, kurumsallaşmanın eksik kaldığı nokta müzakere ile kaybedilen haklara dayanmaktadır. Kurumları agonistik olarak yorumlamak için, bu yapıları oluşturan yapı taşlarını ve temelinde yatan sistemi sorgulamalıyız. Kurumsallaşma uzlaşı arenası olmakla kalmamalı, her karşıt görüşün çekişme yoluyla sesini duyurduğu, çekişmenin ortamı haline gelmelidir (Westphal, 2014). Bunun öncelikli koşulu da demokratik bağlama ortak bir bağlılık yaratmaktır (Lowndes ve Paxton, 2018).

Weber (2009) kurumsallaşmayı rasyonel düşünceye dayalı ve bir denge durumu içinde paylaşılan değerler ve hedefler üzerine inşa edilmiş olarak tanımlamaktadır. Bu geleneksel kurum görüşü, çekişme ve olumsallık ilkeleri ile çelişiyor olsa da, statükoyu üretken çekişmeler ve kurumların temelini oluşturan uzlaşmacı tasarılara meydan okuyacak şekilde yeniden kavramsallaştırmak, kurumları agonizm çerçevesinde yeniden düzenlemenin yolunu açabilmektedir. Agonistik kurumsallaşmada olması gereken temel değişiklik, artık işlevselliğe öncelik veren bakışın yerini, daha çok agonistik alanların ortaya çıkması için önemli fırsatlar sağlayabilecek "belirsizliğin, çekişmenin, çeşitliliğin ve 
olumsallığın" almasıdır (Lowndes ve Paxton, 2018, s. 14). Bu kavramlar kaçınılmaz çatşmanın çekişmeye ve üretici bir güce dönüştürülmesini kolaylaştırır ve teşvik eder. Böylece kurumların agonistik tasarımı, farklı aktörlerin katıl1mıyla çoğulculuğu yansitır ve ortak bir çıarımdan çok tartışma sürecini ön plana alır. Kurumun süreçsel doğası bu sayede yeni değerlerin ortaya çıkmasını sağlar. Agonistik çerçevede kurumsallaşma, karşıt düşüncelerin meşruluğunun kabul edildiği yapıda katılımı teşvik eder. Bu anlamda, çeşitli tarafları yansitan ve mümkün kılan geçirgen bir kurum yapısı tasarlamak önemlidir. Son olarak, olumsallık ilkesine dayalı olarak, demokratik tasarım, açık uçlu bir siyasi süreç olarak anlaşılmalıdır. Bitmişlik üzerine değil, süreç üzerine kurgulanmalıdır. Kesin doğruların olmadığı bu süreçte, çekişme ve beklenmedik durumların benimsenmesi ve kesin olmayan süreçlerin ortaya çlkabileceğinin ("provisional") kabul edilmesi önem taşımaktadır (Lowndes ve Paxton, 2018, s. 23; Mouffe, 2005).

Agonistik yapıdaki kurumların bu özelliklerine dayanarak Lowndes ve Paxton (2018), vatandaşların politik katılımını destekleyen üç yaklaşımı öne sürmektedir. Tüm bu yaklaşımların temelindeki ana fikir, vatandaşların düşüncelerini, karşıt veya lehte, duyurması ve bu düşüncelerin eyleme dönüştürülmesini sağlamaktır. İlk olarak tanımlanan mükemmeliyetçi agonizm ("perfectionalist agonism"), farklı değerlere sahip vatandaşlar arasında bir tercih s1ralaması yaklaşımına işaret eder. Bu yaklaşım, vatandaşları birleştirenin; paylaşılan değerlerin ortaklığından ziyade, ortak bir süreçte yer almaları, sürece katılmalarının olduğunu savunur. (Owen, 1995). İkinci olarak, çekişmeli agonizm ("adversarial agonism”), çoğulcu değerler bağlamında karar vermeye dayanır. Çekişmeli yaklaşım, vatandaşların çekişmelerin gerçekleşebileceği demokratik alanlar sağlamayı ve böylece karşıt görüşlerden doğabilecek çatışmanın başka alanlara kaymasını engellemeyi amaçlamaktadır. Çekişmeli agonizm kurumları, farklı görüşteki vatandaşların birbirlerini ve birbirlerinin fikirlerini meşru kabul etmeyi öğrendikleri, bir çekişme alanını teşvik etmek için hem referandumlardan hem de vatandaş meclislerinden faydalanabilir. $\mathrm{Bu}$ bağlamda, bir kolektif irade evrensellik ve doğruluk iddiasında bulunmaz, daha çok ortak karşıtlığa yönelik çoğul siyasi kimliklerin yakınlaşmasını yansitır (Martin, 2013; McAuliffe ve Rogers, 2019). Son olarak kapsayıcı agonizm ("inclusive agonism"), karşıt görüşlü vatandaşlara farklılıkları ifade etmeleri için bir alan sağlamayı, onları demokratik siyasete dahil etmeyi ve böylece demokratik olmayan çıkışların oluşmasını engellemeyi amaçlamaktadır (Lowndes ve Paxton, 2018). Agonistik davranışlar, itiraz edilebilirliği ve çekişmeyi kabul ederek, farklı grupların birbirlerini kendi kimlikleri için antagonist 
olarak algılamamalarına yardımcı olabilir ve birden fazla kimliğin demokratik alanda birlikte yaşamasını sağlar. Agonizm, daha fazla çeşitlilikte demokratik katılımı, yeniden canlandırılmış bir siyasi alanı, gelişmiş karar vermeyi ve artan sosyal birliği teşvik ederek antagonist çatışmaların üstesinden gelmeyi amaçlar.

\section{Sonuç: Bölge Planlamanın Kurumsallaşmasını Güncel Kuramların Ortak Çerçevesinde Değerlendirmek}

Üç aşamalı olarak incelenen Türkiye'deki bölge planlamanın kurumsallaşma süreci, güncel kuramlar üzerinden bu süreci açıklamada ve neden-sonuç ilişkilerini kurmada bilgi temelini oluşturmuştur.

Birinci evrede odak eyleyenlere bakıldığında Devlet Planlama Teşkilatı ile İmar ve İskan Bakanlığı (sonradan Bayındırlık ve İskan Bakanlığı) arasında kurumlar arası iş birliğinin olduğu görülmektedir (Şekil 6). Bu işbirliği agonizm kuramında bahsedilen karşılıklı bağlllı̆̆ güçlendirici rol oynama potansiyeline sahiptir. Bakanlık üstü özerk denetim mekanizmaları (Bölgesel Gelişme Kurulu ve Komitesi, ve Yüksek Planlama Kurulu) alınan kararların ve iradenin tartışlabilmesini, eleştirilebilmesini sağlarken olumsallığı ve denetimi güçlendirir. Ayrıca Bölgesel Gelişme Komitesi üyelerinin farklı paydaşlardan (STKlar, vatandaş, dernekler) oluşması demokratik çekişme ve tartışmalar için kurumsal altyapı oluşturur. Böylece farklı görüşlerin meşruiyetini tanıyacak ilişki örgüleri kurulur. Ulusal, bölgesel ve yerel düzeyde ilişkilerin kurulması ise 2011'e kadar DPT altında yer alan Kalkınma Ajansları Genel Müdürlüğü ve Bölge Kalkınma idareleri ile sağlanmaktadır. 
Bölgesel Planlamada Kurumsallașmayı Güncel Kuramlarla Değerlendirmek
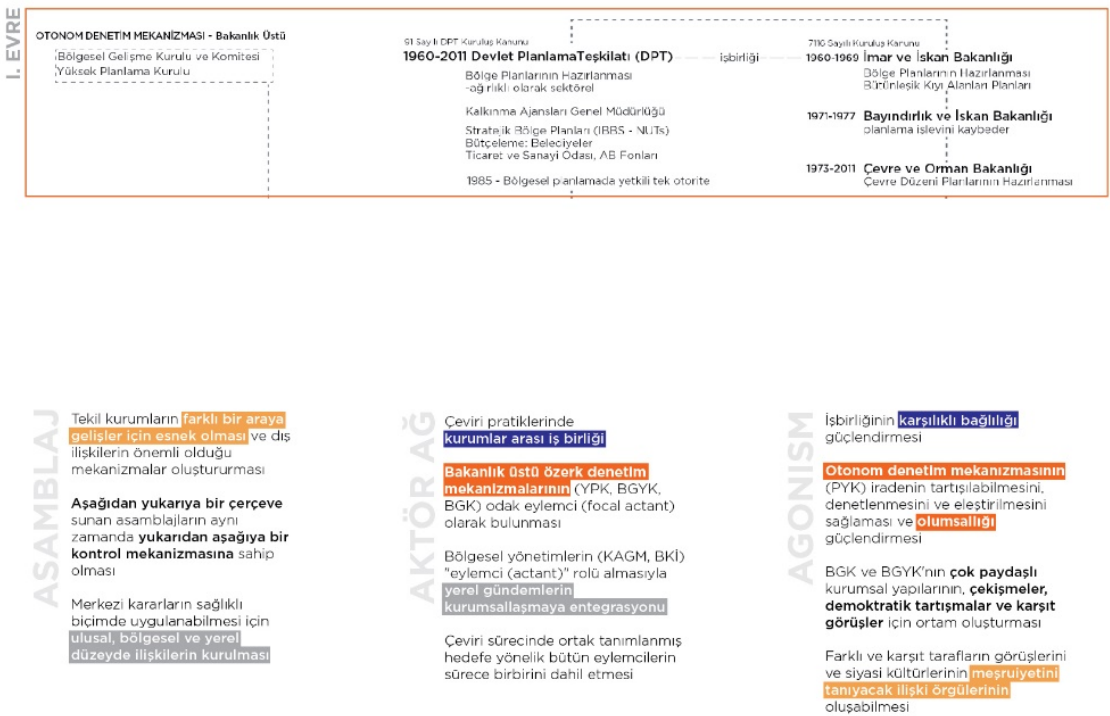

Şekil 6. Türkiye'de bölge planlamada kurumsallaşmanın birinci evresinin güncel kuramlar ortak çerçevesinde incelenmesi

İkinci evre ele alındığında ise en büyük değişimin Devlet Planlama Teşkilatı'nın kapatılması ile bölgesel planlama yapan kurumsal yapının ve denetim mekanizmasının bakanlık üstü, özerk yapısını kaybetmesi olarak gözlemlenmektedir (Şekil 7). Bölgesel plan yapma yetkisinin 2011'de kurulan Kalkınma Bakanlığı'na devri ile merkezileşen ve yukarıdan aşağı kademelenen bir kurumsal yapı ortaya çıkmaktadır. Ayrıca DPT'nin kapatılmasının akabinde kurulan Kalkınma Bakanlığı ile Bayındırlık ve İskan Bakanlı̆̆ı'nın devamı niteliğinde bulunan Çevre ve Şehircilik Bakanlığı'nın bölge planlarında çakışan yetki ve sorumluluklara sahip olduğu görülmektedir (Köroğlu, 2012). Bölge planlarında yetki sahibi olan iki bakanlık arasında işbirliğinin gelişmemiş olması, planlar arasında uyuşmazlıklara zemin oluşturmaktadır. Bu evrede, denetimi ve çoğulculuğu sağlayacak olan kurumlar; Bölgesel Gelişme Kurulu ve Komitesi ve Yüksek Planlama Kurulu özerklik işlevini kaybetmiştir. Çekişmenin ve demokratik tartışma ortamlarının kaybedilmesi, planların meşruiyeti sorusunu gündeme getirmektedir. 

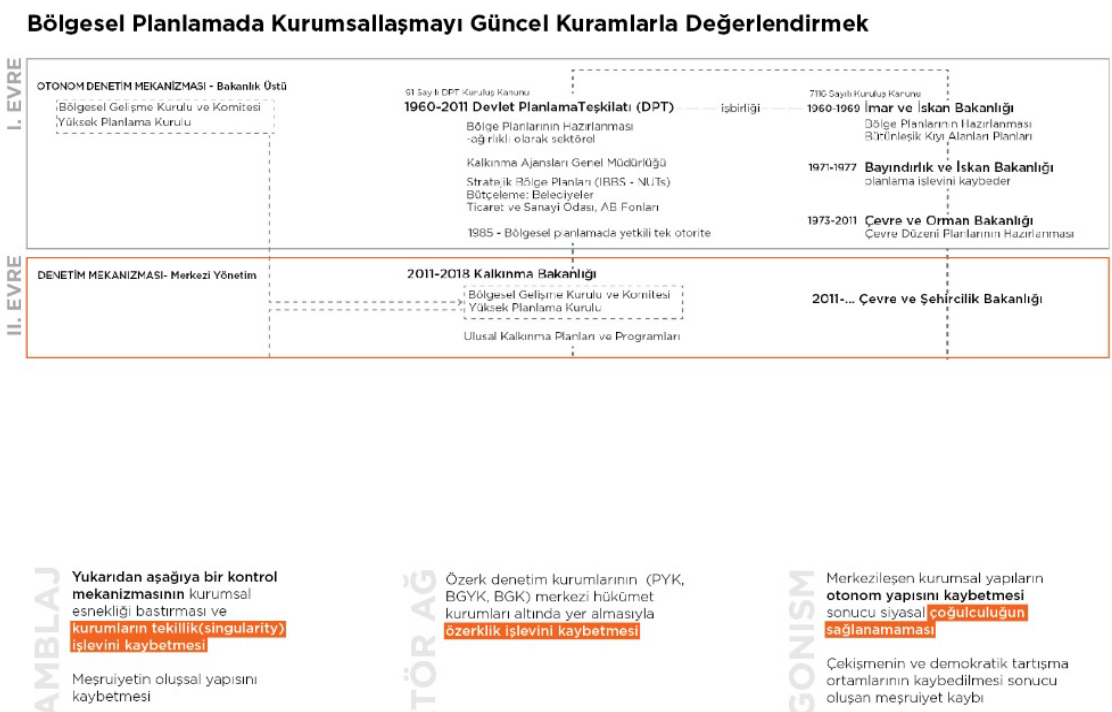

Şekil 7. Türkiye' de bölge planlamada kurumsallaşmanın ikinci evresinin güncel kuramlar ortak çerçevesinde incelenmesi

Birinci aşamada planların sektörel ve mekânsal kısımlarının yetkilerinin iki kurum arasında paylaşıldığı ve bu kurumlar arasında işbirliği sağlanmanın amaçlandığı kurumsal yapı, ikinci aşamada ortaklaşan ve çakışan yetkilere doğru evrilmiştir (Köroğlu, 2012, s. 2). Üçüncü evrede (günümüzdeki evre) ise yetki dağılımın üst üste bindiği, çakışan ama işbirliğinden uzak bir kurumsallaşma görülmektedir (Şekil 8). Bölge tanımının net olmaması, 'plan bölge' s1nırlarının farklılaşması ve kurumlar arasındaki görev dağılımı karmaşası, plan yapma yetkilerini de belirsiz hale getirmektedir (Okcu, Acar ve Akman, 2012; Özçağlar, 2003; Kayan, 2012; Köroğlu, 2012). 2018 yılında Kalkınma Bakanlığı'nın kapatılması ile Ulusal Kalkınma Planları ve Programları'nın oluşturulması yetkisi Strateji ve Bütçe Başkanlığı'na geçmiştir. Öte yandan stratejik bölge planların yapma sorumluluğunu bulunduran Kalkınma Ajansları Genel Müdürlügü ve Bölge Kalkınma İdaresi Teşkilatı, mevcut bulunan Sanayi ve Teknoloji Bakanlığı'na bağlanmıştır (Şekil 8.) Bununla birlikte, bu evrede Çevre ve Şehircilik Bakanlığı'nın yetki ve sorumluluk alanları ise Çevre Düzeni Planları, kırsal alan çalışmaları ve Kalkınma Planları olarak çeşitlenmektedir. Bu üç kurumda üretilen planların ortak paydada buluşması ve sektörel alınan kararla- 
rın mekânsal karşılıklarını bulması, karar alma ve koordinasyondaki muğlaklıktan dolayı sağlanamamaktadır. Mevcut kurumsal şemada çakışan yetkilerden kaynaklı ölçekler arası hiyerarşinin sağlanamaması ve planların uygulama esaslarının belirsizliği göze çarpmaktadır. Bu belirsizlik bölgesel ölçekteki planların oluşturulmasında ve uygulanmasında bölgenin, yani yerelin katılımı ile ilgili soru işaretleri oluşturmaktadır. Yetki devirleri sonucunda kademeli bir birlikteliğin artık yakalanamadığı ortaya çıkmakta ve kurumsal kimlik bulanıklaşmaktadır. Çakışan yetkilerin yarattı̆ı meşruiyet problemi, bir araya gelişlerin sınırını ve kurallarını tanımlayan bölgeselleştirme parametresi ile incelendiğinde, "kimliğini değiştiren" (DeLanda, 2006, s. 138) ya da kaybeden bölgesel çöküşe/yersiz yurtsuzlaşmaya (deterritorialization) doğru evrilen bir süreç karşımıza çımaktadır. DeLanda $(2017$, s. 4) buna benzer süreçleri “... politikaların uygulanması söz konusu olduğunda, iç içe geçen ve örtüşen yargı alanları güçlü bir engel olabilir; çoğu politika, farklı ölçeklerde uygulandıkça çarpıtılır ve zayıflar." diyerek açıklamaktadır. Üst üste gelen yetki sınırları, plan hazırlama yetkisi olan birden fazla kurumun varlığı gibi durumlar, farklı isteklerin, ifadelerin ve kodlamaların ortaya çıkmasına yol açmaktadır. Bu bağlamdaki tutarsızlıklar, plan uygulama aşamasında siyasi isteksizliğe neden olabilir (Kayan, 2012). Ayrıca, Bölgesel Gelişme Kurulu ve Komitesi ile Yüksek Planlama Kurulu'nun işlevini yitirmesi ile çekişme arenaları yok olmaktadır. Bunun sonucunda bugün içselleştirilmemiş proje ve politikalar çoğalmakta ve bu çalışmalara farklı paydaşlar tarafından verilen tepkiler artmaktadır. Kısacası bugün agonizmden ziyade antagonizme yakın bir yapıya doğru sürüklenen bir kurumsallaşma gözlenmektedir. Denetimden ve koordinasyondan sorumlu Yüksek Planlama Kurulu ve Bölge Gelişme Kurumlarının kaldırılması ile tartşılmayan söylem ve projeler yaygınlaşmaktadır. Bu da ileriki karar alma süreçlerinde demokratik dışlanmışlığa ve siyasal ilgisizliğe yol açarak, katilımın düşmesine neden olabilmektedir. 


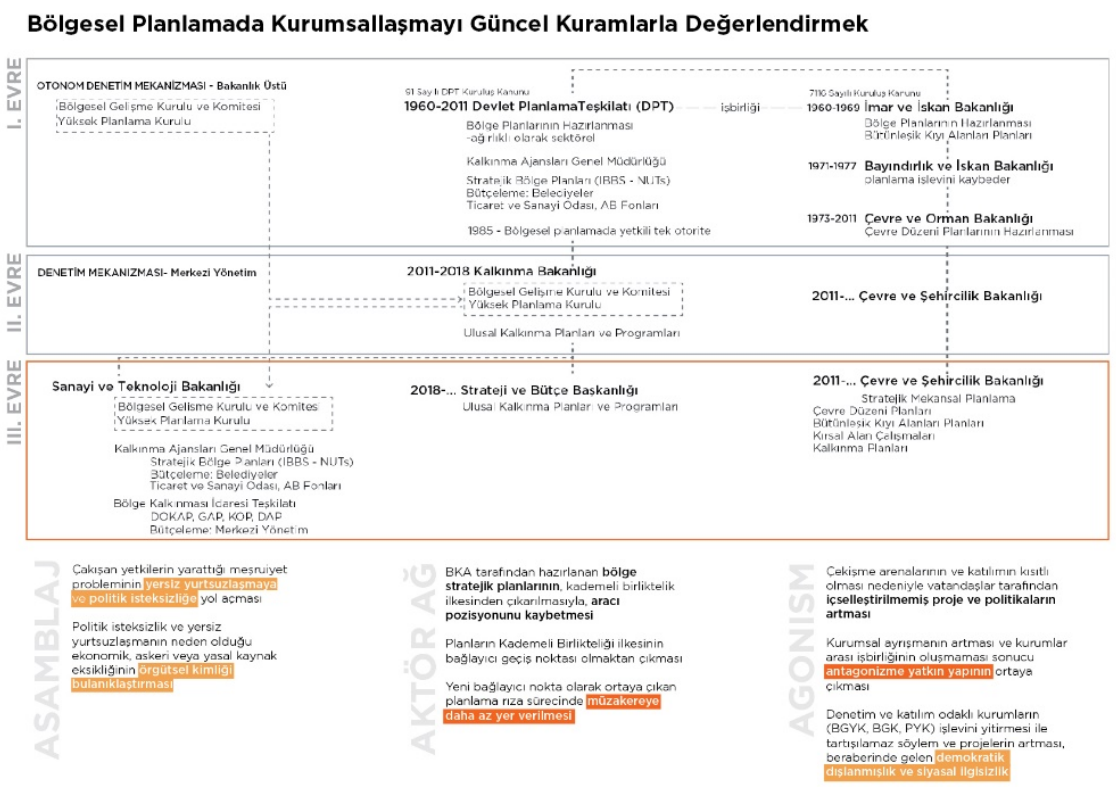

Şekil 8. Türkiye'de bölge planlamada kurumsallaşmanın üçüncü evresinin güncel kuramlar ortak çerçevesinde incelenmesi

Sonuç olarak, Türkiye'de bölge planlama pratiği sürecinde pek çok değişim yaşanmış, bu değişimlerin odağında ise kurumsallaşmada gerçekleşen keskin geçişlerin karar alma mekanizmalarına, bu mekanizmaların meşruiyetlerine etkisi olmuştur. Bu karmaşık ve değişken yapı karar alma mekanizmasını etkilediği gibi planların uygulama aşamasında karşılaştığı sorunlara da zemin hazırlamıştır.

Bu çalışma kapsamında daha önce de vurgulandığı gibi fiziksel, insan ya da sosyal her türlü sermaye aracı olmanın temel kaynağını oluşturmaktadır. Çoğu kurum ya da çoğu plan, bölgede yaşayan insanların, bölgesel kalkınmadaki en kritik eyleyen olarak, plan, program ya da proje kapsaminda önerilen yeni aktivitelere yatırabileceği yeterli finansal kaynaklara sahip olup olmadığını sorgulamaktadır. Aynı şekilde, belirli bölgelerdeki insan sermayesi ya da sosyal sermayenin nasil oluşturulabileceğine ya da mevcut sermayenin nasıl harekete geçirilebileceğine yönelik kaygılar bulunmamaktadır.

Plan yapım süreci, yerelden olduğu kadar, kurumlar bünyesinde saklanan geçmiş verinin elde edilmesi ve işlenmesiyle bütünlük kazanmaktadır. Bu sebeple, açık kaynak kullanımları ve kurumlar arası veri paylaşımı şeffaflık, iş birliği ve kurumsal hafızanın sürdürülmesi için önem kazanmaktadır. Fakat, 
her kurumun yetki ve görevlerinin yeni oluşan bir diğer kuruma aktarılmasıyla dijital ve materyal verinin kaybedilmesi durumu ortaya çıkmaktadır. Tarihsel bir sürekliliğin olmadığı bir kurumsallaşma ortamında, geçmişte oluşturulan bilgi temelinin geleceğe yönelik bir plan yapmada ve kurumsallaşmanın evrimsel süreçlerinin izini sürmede etkili olacağını söylemek imkansızdır. Ayrıca, bunun gibi çabaların olmadığı bir kurumsallaşma sürecinde, bölgesel plan ve politikaların aktör ağda sadece yeni bağlantılar kuran aracilar pozisyonundan öteye geçmesi mümkün olmamaktadır.

Son olarak, plan sürecinde daha çoğulcu bir mekanizmanın olması özerk bir kurumsal yapının karşıt görüşlerin ortaya konması için bir arena oluşturması ile imkân kazanacaktır. Bu çerçevede kurumsallaşan bir çekişme alanı, farklı görüşlerin katılımcı bir anlamda ortaya konduğu ve karşıt görüşlerin birbirini meşru saymasının olanağının ortaya çıktı̆̆ı, süreci odağına alan, farklı düzeylerde agonistik yapıların başlangıcı olabilecektir. 


\title{
Extended Abstract
}

\section{Institutionalisation of Regional Planning in Turkey: Rendering an Ambiguous Process with Recent Theories}

\author{
* \\ Irmak Yavuz \\ ORCID: 0000-0001-5735-5599 \\ Ecem Kutlay \\ Deniz Can \\ ORCID: 0000-0002-3406-5115 ORCID: 0000-0003-2681-526X
}

The institutionalisation process of regional planning in Turkey presents sudden shifts in terms of contents, objectives and institutional structures. Changes in the institutional framework and in the jurisdiction of regional planning institutions have affected decision-making mechanisms and the success of plans. The institutional structure of regional planning has become fragmented due to these changes in recent years. This fragmentation disrupted the cooperation among emerging institutions and the coordination between plans that were produced by separate institutions to meet different ends. Unstable state of institutional framework of regional planning has become an obstacle against the effectiveness of regional plans and has put a limit to fulfill regional potentials. At that point, emerging theoretical frameworks provide a basis to keep track of ever-changing institutional framework, to assess its impacts on regional planning practice and to generate further discussions. To that end, this article draws on; first, assemblage and actor-network theory (ANT) as a conceptual framework and a methodological avenue for the depiction of different phases of evolving institutional frameworks and unsteady multi-actor structures, and second, agonism theory as a framework for democratic processes in multi-agency planning practices.

The assemblage theory (DeLanda 2006; 2017), based on the theoretical framework of assemblage developed by Deleuze and Guattari, offers a robust basis to support the understanding of the complex and multi-layered nature of cities and their planning structures at any scale. Indeed, its theoretical premise 
potentially functions as a guide for evaluating the changes in the institutionalization process of regional planning in Turkey. Assemblage theory argues that the parts and the relations established between them are ever changing. At this point, the parts that create a whole have the potential to create a different whole and thus, relations. Inevitably, a complex relational structure emerges and this kind of complexity is analyzed through two parameters; territorialization and coding (DeLanda, 2017). These parameters and the concepts shed light on the major reasons behind the overlapping jurisdictional boundaries, changing authorities and the unwillingness of planmaking in the regional planning system in Turkey.

In an era when not only global forces, but also local dynamics that enable and mobilise globalism are scrutinized, ANT attracts particular attention in the theory and practice of urbanism. The objective of unveiling interactions in locality necessitates the reading of events as heterogeneous performances that are inherently complex and unpredictable. At this juncture of complexity and uncertainty, ANT is employed to capture instants of an ever-changing institutional process. By delving into how obligatory passage points shift, how focal actants are formed, what sort of relations are established, and what kind of characteristics the intermediaries present, this article scrutinizes the formation and the transformation of actor-network topologies in the institutionalization of regional planning in Turkey.

The article indicates that 'planning consent process' and 'gradual unity principle' emerge as the two distinctive sources of obligatory passage points. The shifts in the obligatory passage points also signal the change of focal actants in the network topology. Actor-network analysis of regional planning in Turkey presents three phases of institutionalisation: (I) Autonomous supervision mechanisms and State Planning Organization (SPO) as the focal actant (1960-2011), (II) Ministry of Development and Ministry of Environment and Urbanism as focal actants (2011-2018), (III) Presidency and related institutions as emerging supervision mechanisms (2018-ongoing). To elaborate, the formation of associations over time demonstrates that focal actants of the actor-network change rapidly after the turn of the century. More importantly, the relative position of the initial supervision mechanisms critically shifts in the network. The first phase presents a network where focal actants were constituted by autonomous institutions (Regional Development Higher Committee and Regional Development Council) that undertake supervision, coordination, budgeting and establishing a general regional policy framework, and agencies (SPO) that take the 
role of assisting central government through facilitating coordination and offering consultancy. Whereas, the second phase presents a network where central state institutions such as Ministry of Development act as focal actants through the allocation of previously autonomous institutions under central state institutions as well as the attribution of the role of supervision to the central government. Lastly, the third phase illustrates emerging sovereignty of presidential institutions over regional planning authorities. In that sense, how the future actor-network topology will take its shape has become one of the major questions recently since Turkey entered a new phase of institutionalisation with the introduction of presidential system.

The changing institutional structures, objectives and practices in regional planning along with the current fragmented and overlapping distribution of power and responsibilities cause a democratic deficit, and consequently results in the production of projects and formulation of policies that are not internalized. The emerging political theory of agonism presents a new institutional approach through giving emphasis on opposing views, conflicts and democratic contestations, rather than the aim of building consensus. As a political theory, it rejects the consensual approach of currently dominant communicative and collaborative theory. By agonistic democracy it would be possible to recognize each political culture and, through mutual respect each side could coexist even in conflicting political situations. This political pluralism is only possible by mutual understanding and recognition. The idea of agonism is examined in the context of promoting discourse, contestations and flexibility. To that extent, how it would be possible to penetrate the constructive and participative discourse idea of agonistic democracy in the institutionalization process of Turkish regional planning is discussed.

In the concluding part, the article evaluates institutionalisation of regional planning in Turkey with a joint framework of assemblage, actor network and agonism theories. The characteristics of the three phases of institutionalisation are discussed within this relational framework. The collaboration among institutions as the major characteristics of the first phase, facilitates the mutual commitment between different bodies as the basic premise of agonism theory. Moreover, autonomous supervision mechanisms functioning above the ministries provide a ground for criticism and debate. Furthermore, multiple-actor composition in supervision mechanism is an indicator of an institutional structure that enables democratic contestation. In the second phase, with the centralisation of regional planning institutions, a top-down vertical hierarchy in the ins- 
titutional structure supersedes the horizontal one with autonomous supervision mechanisms. This indicated a deficit in the arenas of contestation and pluralism. In the third phase, the institutional structure becomes antagonistic rather than agonistic with the overlapping jurisdictional frameworks of institutions and with the production of incompatible plans.

Overall, the cross assessment of institutional structure through recent theories provides a comprehensive glance on the institutionalization process. Eventually, this article offers a fresh perspective to frequently discussed issues in the regional planning practice through recent theories and concepts. Nevertheless, it becomes even more challenging to investigate institutionalization processes in the context of regional planning in Turkey, since the mechanisms of regional planning practice have become vague with the new institutional arrangements.

\section{Kaynakça/References}

Akgül, B., ve Efe, M. (2010). Dünyada ve Türkiye'de bölge planlama çalışmaları ve bunların karşlaş̧tırılması. Çağdaş Yerel Yönetimler, 19(4), 19-45. 10 Ocak 2020 tarihinde https://atif.sobiad.com/index.jsp?modul=makale-detay\&Alan=sosyal\&Id=AV_T_OXdoDuH9Br_b3W4 adresinden erişildi.

Arslan İ. K. (2005). Bölgesel kalkınma farkllıklarının giderilmesinde etkin bir araç: Bölgesel planlama ve Bölgesel Kalkınma Ajansları. İstanbul Ticaret Üniversitesi Sosyal Bilimler Dergisi, 4(7), 275-294. 10 Ocak 2020 tarihinde https://atif.sobiad.com/index.jsp?modul=makale-detay\&Alan=sosyal\&Id=AWMGUJtIIwYof_IhoVBy adresinden erişildi.

Arslan, G. E., ve Demirel, B. (2010). Türkiye'de bölgesel politikaların gelişimi ve bölgesel dengeler. Ankara Sanayi Odast Dergisi, 51-64. 20 Ocak 2020'de https://dergipark.org.tr/en/pub/ataunisosbil/issue/2836/38669 adresinden erişildi.

Atkinson, P. (2016). Assemblage and différance: An institutional theory and methodology. (Yayımlanmamış doktora tezi).Brunel University, London. 20 Ocak 2020'de https:/bura.brunel.ac.uk/bitstream/2438/14813/1/FulltextThesis.pdf adresinden erişildi.

Bäcklund, P., ve Mäntysalo, R. (2010). Agonism and institutional ambiguity: Ideas on democracy and the role of participation in the development of planning theory and practice-the case of Finland. Planning theory, 9(4), 333-350. 20 0cak tarihinde https://www.jstor.org/stable/26004241 adresinden erişildi.

Boelens, L. (2011). Going beyond planners' dependencies: An actor-relational approach to Mainport Rotterdam. Town Planning Review, 82(5), 547-572. 18 Ocak 2020 tarihinde https://www.jstor.org/stable/41300333 adresinden erişildi.

Callon, M. (1990). Techno-economic networks and irreversibility. The Sociological Review, 38(1_suppl), 132-161. doi:10.1111/j.1467-954X.1990.tb03351.x 
Clough, P., Han, S., ve Schiff, R. (2007). Book review: A new philosophy of society: Assemblage theory and social complexity by Manuel DeLanda London and New York: Continuum, 2006. Theory, Culture \& Society, 24(7-8), 387-393. doi:https://doi.org/10.1177/0263276407086408

Cvetinovic, M., Nedovic-Budic, Z., ve Bolay, J. C. (2017). Decoding urban development dynamics through actor-network methodological approach. Geoforum, 82, 141-157. doi:https://doi.org/10.1016/j.geoforum.2017.03.010

Çalt, G. (2005). Bölgeselleşme ve Avrupa Birliği'nin bir aracı olarak Bölge Kalkınma Ajansları. VI. Türkiye Ziraat Mühendisliği Teknik Kongresi Bildiri Metinleri, 3-7. 10 Ocak 2020 tarihinde https://www.zmo.org.tr/resimler/ekler/8df7b8e8d586a55_ek.pdf?tipi=14\&turu=X\&sube=0 adresinden erişildi.

DeLanda, M. (2006). A new philosophy of society: Assemblage theory and social complexity. London-New York: Continuum.

DeLanda, M. (2017). Deleuzian social ontology and assemblage theory [PDF Dosyasi]. 13 Ocak 2020 tarihinde https://www.researchgate.net/publication/297700098_Deleuzian_Social_Ontology_and_Assemblage_Theory adresinden erişildi.

Deleuze, G., ve Parnet, C. (1987). Dialogues (H. Tomlinson ve B. Habberjam, Çev.). The Athlone Press, London.

Deleuze, G., ve Guattari, F. (1987). A thousand plateaus: Capitalism and schizophrenia (B. Massumi, Çev.). University of Minnesota Press, Minneapolis, London.

Derdiman, R. C. (2015). Başbakanlık ve bakanlık teşkilatlarında kanun hükmünde kararnamelerle yapılan değişiklikler ve hukukî sonuçları. Ankara Hacı Bayram Veli Üniversitesi Hukuk Fakültesi Dergisi, 19(4), 189-226. 11 Ocak 2020 tarihinde https://dergipark.org.tr/tr/download/article-file/789051 adresinden erişildi.

Ersoy, M. (2006). İmar mevzuatımızda planlama kademeleri ve üst ölçek planlama sorunu. Bölgesel Kalkınma ve Yönetişim Sempozyumu Bildiriler Kitabı, 215-231. 25 Ocak 2020'dehttps://www.tepav.org.tr/sempozyum/2006/bildiri/bolum3/3_2_ersoy.pdf adresinden erissildi.

Fedai, R. (2016). Devlet Planlama Teşkilatı'ndan Kalkınma Bakanlığı'na: Planlama anlayıŞında yaşanan değişim. SOBİDER, 3(9), 410-422. doi:10.16990/SOBIDER.3307

Kayan, A. (2012). Türkiye'de bölge planlaması: Sorunlar ve çözüm önerileri. Mustafa Kemal Üniversitesi Sosyal Bilimler Enstitüsü Dergisi, 9(20), 103-134. 16 Ocak 2020 tarihinde https://dergipark.org.tr/en/pub/mkusbed/issue/19549/208405 adresinden erişildi.

Kayasü, S. ve Yetişkul, E. (2013). Bir araştırma çerçevesi: Soylulaştırma 2.0. Planlama Dergisi, 23(3), 147-152. doi:10.5505/planlama.2013.43531

Köroğlu, T. (2012). KHK'ler sonrasında bölge planlamanin geleceği karmaşa mı, işbirliği mi? Politika Notu, Türkiye Ekonomi Politikaları Araştırma Vakfı (TEPAV). 11 Ocak 2020 tarihinde https://www.tepav.org.tr/upload/files/1329914909-3.KHK_ler_Sonrasinda_Bolge_Planlamanin_Gelecegi_Karmasa_mi_Isbirligi_mi.pdf adresinden erişildi. 
Latour, B. (2005). Reassembling the social: An introduction to actor-network-theory. Oxford University Press.

Leblebici, D. N., ve Erkul, E. (2008). Planlı kalkınma deneyiminden stratejik planlamaya geçiş: Türkiye örneği. Hacettepe Üniversitesi İktisadi ve İdari Bilimler Fakültesi Dergisi, 26(1). 20 Ocak 2020 tarihinde https://dergipark.org.tr/tr/download/article-file/303585 adresinden erişildi.

Lowndes, V., ve Paxton, M. (2018). Can agonism be institutionalised? Can institutions be agonised? Prospects for democratic design. The British Journal of Politics and International Relations, 20(3), 693-710. doi:https://doi.org/10.1177/1369148118784756

Martin, J. (Der.). (2013). Chantal Mouffe: Hegemony, radical democracy, and the political. Routledge.

McAuliffe, C., ve Rogers, D. (2019). The politics of value in urban development: Valuing conflict in agonistic pluralism. Planning Theory, 18(3), 300-318. doi:https://doi.org/10.1177/1473095219831381

McClymont, K. (2011). Revitalising the political: Development control and agonism in planning practice. Planning Theory, 10(3), 239-256. doi:https://doi.org/10.1177/147309521139939

Mouffe, C. (1999). Deliberative democracy or agonistic pluralism? Social Research, 66(3), 745-758. 12 Ocak 2020 tarihinde https://www.jstor.org/stable/pdf/40971349.pdf adresinden erişildi.

Mouffe, C. (2005). The limits of John Rawls's pluralism. Politics, Philosophy \& Economics, 4(2), 221-231. doi:https://doi.org/10.1177/1470594X05052539

Mouffe, C. (2013). Agonistics: Thinking the world politically. Verso Books.

Murdoch, J. (1997). Towards a geography of heterogeneous associations. Progress in Human Geography, 21(3), 321-337. doi:https://doi.org/10.1191/030913297668007261

Murdoch, J. (1998). The spaces of actor-network theory. Geoforum, 29(4), 357-374. doi:https://doi.org/10.1016/S0016-7185(98)00011-6

Mutlu, S. (2008). Türkiye'de Bölge Planlama Deneyimleri: Eleştirel Bir Yaklaşım. 3. Bölgesel Kalkınma ve Yönetişim Sempozyumu'nda sunulan bildiri, Mersin, Türkiye. 12 Ocak 2020 tarihinde https:/www.tepav.org.tr/sempozyum/2008/bildiriler/servet_mutlu.pdf adresinden erişildi.

Müller, M., ve Schurr, C. (2016). Assemblage thinking and actor-network theory: Conjunctions, disjunctions, cross-fertilisations. Transactions of the Institute of British Geographers, 41(3), 217-229. doi:https://doi.org/10.1111/tran.12117

Nail, T. (2017). What is an Assemblage? Substance, 46(142), 21-37. 15 Ocak 2020 tarihinde https://muse.jhu.edu/article/650026/pdf adresinden erişildi.

Okcu, M., Acar, O. K., ve Akman, E. (2012). Türkiye'de bölgesel kalkınma planları vizyon, stratejik amaç ve hedefleri üzerine analitik bir inceleme. Süleyman Demirel Üniversitesi Fen-Edebiyat Fakültesi Sosyal Bilimler Dergisi, 27, 231-246. 15 Ocak 2020 tarihinde https://dergipark.org.tr/tr/pub/sufesosbil/issue/11410/136263 adresinden erişildi.

Owen, D. (1995). Nietzsche, politics and modernity a critique of liberal reason. Sage. 
Özçağlar, A. (2003). Türkiye' de yapılan bölge ayrımları ve bölge planlama üzerindeki etkileri. Coğrafi Bilimler Dergisi, 1(1), 3-18. 12 Ocak 2020 tarihinde https://dergipark.org.tr/en/pub/aucbd/issue/44494/551617 adresinden erişildi.

Özyurt, H. (2012). Genel olarak bölge ve alt bölge planlaması ve Türkiye'de alt bölge planlamasına duyulan ihtiyaç. Sosyal Siyaset Konferansları Dergisi, 0(31), 449-468. 9 Ocak 2020 tarihinde https://dergipark.org.tr/en/pub/iusskd/issue/922/10441 adresinden erişildi.

Palmer, J. S. (2014). Network mapping of housing systems: The case of medium-density dwelling design in Australia. RSD3, Third Symposium of Relating Systems Thinking to Design'da sunulan bildiri, Oslo, Norveç. 16 Ocak 2020 tarihinde http://openresearch.ocadu.ca/id/eprint/2103/ adresinden erişildi.

Pløger, J. (2004). Strife: Urban planning and agonism. Planning Theory, 3(1), 71-92. doi:https://doi.org/10.1177/1473095204042318

Rodger, K., Moore, S. A., ve Newsome, D. (2009). Wildlife tourism, science and actor network theory. Annals of Tourism research, 36(4), 645-666. doi:https://doi.org/10.1016/j.annals.2009.06.001

Roskamm, N. (2015). On the other side of "agonism":"The enemy," the "outside," and the role of antagonism. Planning Theory, 14(4), 384-403. doi:https://doi.org/10.1177/1473095214533959

Ruming, K. (2008). A new network direction in housing studies: the case of actor-network theory. 3rd Annual Australasian Housing Researchers' Conference'da sunulan bildiri, RMIT University, Melbourne, Avustralya. 16 Ocak 2020 tarihinde https://www.be.unsw.edu.au/sites/default/files/upload/research/centres/cf/CFpresentations/AHRC08Ruming.pdf adresinden erişildi.

Ruming, K. (2009). Following the actors: Mobilising an actor-network theory methodology in geography. Australian Geographer, 40(4), 451-469. doi:https://doi.org/10.1080/00049180903312653

Rydin, Y. (2013). Using Actor-Network Theory to understand planning practice: Exploring relationships between actants in regulating low-carbon commercial development. Planning Theory, 12(1), 23-45. doi:https://doi.org/10.1177/1473095212455494

Salet, W. (Der.). (2018). The Routledge handbook of institutions and planning in action. Routledge.

Serin, G. (2006). Türkiye'de bölgesel gelişim ve yeni bölgecilik Karaman örneği (Yayımlanmamış doktora tezi), Selçuk Üniversitesi Sosyal Bilimler Enstitüsü, Konya. 10 Ocak 2020 tarihinde

https://tez.yok.gov.tr/UlusalTezMerkezi/tezDetay.jsp?id=D1OvuYRqu77yntv5uF8XDg\&no=TEQPGKHdITTAN_URvZT2A adresinden erişildi.

Sert, O. (2012). Kalkınma ajansları ve üst ölçekli planlar. Akademik Araştırmalar ve Çalışmalar Dergisi (AKAD), 4(6), 99-128. 15 Ocak 2020 tarihinde https://dergipark.org.tr/tr/download/article-file/180472 adresinden erişildi.

Skowronek, S. (1995). Order and change. Polity, 28(1), 91-96. doi:https://doi.org/10.2307/3235188 
Tait, M., ve Jensen. O. B. (2007). Travelling ideas, power and place: The cases of urban villages and business improvement districts. International Planning Studies, 12(2). 107-128. doi: https://doi.org/10.1080/13563470701453778

Taneri, E. (1986). Bölge planlama. İstanbul: Doğan Matbaası 1986. Yıldız Üniversitesi Yayınları Sayı: 186

Tutar, E., ve Öztürk, N. (2010). Türkiye'de gerçekleştirilen bölgesel planlama çalışmaları. Atatürk Üniversitesi İktisadi ve İdari Bilimler Dergisi, 17(1-2). 1-20. 12 Ocak 2020 tarihinde https://dergipark.org.tr/tr/pub/atauniiibd/issue/2685/35246 adresinden erişildi.

Weber, M. (2009). The theory of social and economic organization. Simon and Schuster.

Wenman, M. (2003). 'Agonistic pluralism'and three archetypal forms of politics. Contemporary Political Theory, 2(2), 165-186. doi:https://doi.org/10.1057/palgrave.cpt.9300091

Westphal, M. (2014). Applying principles of agonistic politics to institutional design. ECPR General Conference'da sunulan bildiri Glasgow, İskoçya. 16 Ocak 2020 tarihinde https:/ecpr.eu/Filestore/paperproposal/6a607c02-3a40-493d-abbc-a0c0bd587551.pdf adresinden erişildi. 